\title{
The Relation between Strategy, CEO Selection, and Firm Performance*
}

\author{
MARGARET A. ABERNETHY, The University of Melbourne ${ }^{\dagger}$ \\ YU FLORA KUANG, The University of Melbourne \\ BO QIN, The University of Melbourne
}

\begin{abstract}
We examine whether a firm's strategic priorities influence its selection of a new CEO and what conditions enable such an appointment to add value to the firm. More specifically, this study investigates the value-adding effect when prospector firms (i.e., those pursuing a prospector-type strategy) select a CEO with high social capital. We argue that uncertainty, driven by a firm's strategy, will determine the decision to select a CEO with high social capital; such CEOs can use their networks to mitigate the uncertainty and thus can be valuable to the firm. However, prior research indicates that CEOs with high social capital can engage in behavior detrimental to firm value. To mitigate the potential for this to occur, we assess whether corporate governance can play a role in prospector firms who appoint CEOs with high social capital. Drawing on archival data of CEO successions over a 14-year period, we find that prospector firms have greater incentives to appoint CEOs with high social capital. We also find prospector firms who appoint a CEO with high social capital improve their performance. Furthermore, the value-adding effect of this selection choice is stronger in prospector firms with good corporate governance.
\end{abstract}

Keywords: firm strategy; social capital; CEO selection; corporate governance; firm value

* Accepted by Ranjani Krishnan. We thank Michael Welker, Ranjani Krishnan, and two anonymous referees for their most constructive advice throughout the entire review process. We appreciate the helpful comments of Steven Balsam, Mary Barth, Liesbeth Bruynseels, Martin Bugeja (discussant), Shuping Chen, Henri Dekker, Ian Gow, Reggy Hooghiemstra, Chung-Yu Hung, Christo Karuna (discussant), David Larcker, Richard Lee, Anne Lillis, Laurence van Lent, Kelvin Liu, Hai Lu, Vic Naiker, Sujay Nair, Valeri Nikolaev, Matt Pinnuck, Naomi Soderstrom, Sharon Soltys (discussant), Jeroen Suijs, Ann Tarca, Paula van Veen-Dirks, Mark Wallis, Arnie Wright, Wei Zeng, Yachang Zeng, and the seminar participants at the University of Melbourne, Nanyang Technological University, La Trobe University, and UWA Business School. We also thank participants at 2016 UTS Summer Accounting Conference at Sydney and 2017 Global Management Accounting Research Symposium at Sydney.

† Corresponding author: Margaret A. Abernethy, The University of Melbourne, Faculty of Business and Economics, Department of Accounting, Level 7, 198 Berkeley Street, Victoria 3010, Australia, Phone: +61 3834 45716. E-mail: m.abernethy@unimelb.edu.au.

This is the author manuscript accepted for publication and has undergone full peer review but has not been through the copyediting, typesetting, pagination and proofreading process, which may lead to differences between this version and the Version of Record. Please cite this article as doi: 10.1111/1911-3846.12463

This article is protected by copyright. All rights reserved. 


\section{Introduction}

We are interested in understanding what influences the appointment of a new CEO and when these appointments add value. Given that strategy is considered the most critical choice a firm makes (Van den Steen 2016, 2017; Vancil 1987) we commence with understanding how a firm’s strategy influences their selection of a new CEO. ${ }^{1}$ Selection is a deliberate control choice (Abernethy, Dekker, and Schultz 2015; Campbell 2012) and the appointment of a new CEO is a key responsibility of a corporate board (Bennis and O’Toole 2000; Murphy and Zábojník 2004, 2007). We know little about which CEO qualities are important to a board when making the selection decision. While CEO human capital (e.g., education, experience, expertise) is an important input into these decisions there is also evidence that an individual's social capital can be equally, if not more important, in particular circumstances (Belliveau et al. 1996; Erkens and Bonner 2013; Kilduff and Tsai 2003). We first examine whether a firm’s strategic priorities explain its choice in appointing a CEO with high social capital, and second we test whether this appointment choice increases firm value. We also assess whether good corporate governance enhances the value-adding effect of appointing a CEO with high social capital.

A CEO’s social capital (also known as "relational capital”) is the network of relationships accumulated by a CEO’s connections through corporate board memberships, trusteeships, memberships in social clubs, their alma mater, etc. (Cohen et al. 2014; Engelberg et al. 2012). ${ }^{2}$

\footnotetext{
${ }^{1}$ Van den Steen (2016) also argues that all other organizational choices flow from a firm's choice of strategy (e.g. selection and recruitment, structure, performance measurement, and reward decisions).

${ }^{2}$ In this paper, a CEO's social ties, social capital, relational capital, social relationships, social networks, connections, and connectedness are interchangeable terms.
} 
There is also anecdotal evidence that corporate boards place importance on a CEO's social capital in the selection decision, as social capital can capture particular qualities not reflected in traditional metrics of human capital (Belliveau et al. 1996; Erkens and Bonner 2013). ${ }^{3}$ We argue that the strategic priorities of a firm will increase the importance placed on social capital when appointing a new CEO. The choice of strategy can create uncertainty for the firm (Desarbo et al. 2005; Doty et al. 1993; Hambrick 1983; Miller 1988). Appointing a CEO with high social capital is a means of mitigating uncertainty as a CEO's network can provide access to the strategic information and resources needed to manage in an uncertain context (Geletkanycz and Hambrick 1997; Schoorman et al. 1981; Useem 1982).

We classify firms using the prospector/defender strategic typology developed by Miles and Snow (1978). One of the defining features of this typology is the level of uncertainty associated with prospectors compared to defenders. While there are other strategic typologies available to describe a firm's strategy, ${ }^{4}$ the Miles and Snow typology continues to be used to examine the different strategic choices that a firm makes. The typology is also useful given that

\footnotetext{
${ }^{3}$ For example, the press release when Morgan Stanley announced the appointment of its new CEO in 2005 refers specifically to the value the new CEO will bring to the firm with his 30 years of experience working with investors, clients, and industry leaders. In another example, Health Care Property Investors highlight that the new CEO appointed in 2003 will bring to the company "a clear and focused vision, ... along with substantial relationships with senior health care executives.”

${ }^{4}$ For example, the product life cycle classification or whether a firm is a cost leader or differentiator. These classifications are similarly distinguished based on uncertainty faced.
} 
measures have been developed and validated using archival data to capture the prospector/defender archetypes (e.g., Bentley et al. 2013). ${ }^{5}$

We expect that prospector-type firms have greater incentives to select a CEO with high social capital compared to a defender-type firm. ${ }^{6}$ Prospectors face a higher level of strategic uncertainty as they must continually adapt to the changing needs of customers, and search for ways in which to differentiate their products or services (Miller 1988, 1991; Waldman et al. 2001). By appointing CEOs with high social capital, a firm pursuing a prospector-type strategy can utilize the CEOs' social networks to access operational and strategic information and resources, and in turn, mitigate strategic uncertainty and generate value. We also expect that firm value of prospectors is further enhanced when good corporate governance is in place. CEOs with high social capital can engage in behavior that is detrimental to the firm (Fombrun 1996; Malmendier and Tate 2009; Milbourn 2003). Good corporate governance constrains managerial opportunism and mitigates the plausible agency costs associated with appointing CEOs with high social capital. Thus, the value-adding effect of appointing a CEO with high social capital in prospector firms will be enhanced with good corporate governance while limited under poor governance.

\footnotetext{
${ }^{5}$ Our model recognizes that a firm can be placed along a prospector and defender continuum; that is, firms are not classified as either a pure defender or a pure prospector. Accordingly, we use the terms "prospector-type" or "defender-type" to reflect this.

${ }^{6}$ While CEO connectedness can add value to all firms, we do not expect defender-type firms to deliberately seek to address their information needs by appointing a CEO with high social capital as these individuals are typically more costly to hire, impose risk, and there might not be significant incremental value associated with such appointments (Faleye et al. 2014; Kilduff and Krackhardt 2008).
} 
Our empirical findings support our predictions. First, we show that prospector-type firms tend to appoint CEOs with high social capital. Second, we find that these firms have improved performance, suggesting that the decision to appoint CEOs with high social capital is positively associated with firm value. Additional analysis also indicates that the market reaction to such appointments is positive. And finally, our results show that good corporate governance strengthens the value-adding effect of CEO social capital for prospector firms. In other words, it is a confluence of prospector-type strategies, high CEO social capital, and strong governance that adds most to firm value. Our primary findings are robust to controlling for selection bias at CEO recruitment, a variety of alternative explanations, placebo variables, and alternative proxies for strategic priorities and firm performance.

We also address several additional questions raised in the prior literature. In particular, we document that CEOs with high social capital invest more in R\&D and SG\&A compared to CEOs with low social capital, providing evidence of plausible channels through which social networks can add value to a firm. We further find that prospector-type firms place importance on both professional and friendship-based networks. We confirm prior research findings that firms pay a compensation premium to CEOs with high social capital (Geletkanycz et al. 2001; Granovetter 1973; Kilduff and Krackhardt 2008). And finally, we find evidence that firms can use equity incentives as a bonding mechanism to mitigate the potential agency costs associated with appointing CEOs with high social capital, but it works only when good corporate governance is in place. 
Our study makes several contributions. First, we contribute to the CEO succession literature by demonstrating that a firm's strategic priorities influence the selection of a new CEO (Allgood and Farrell 2003; Farrell and Whidbee 2003; Larcker et al. 2014, 2016; Tian et al. 2011). CEO succession has received considerable attention in the literature (Barron et al. 2011; Parrino 1997; Shen and Cannella 2002), and is a major concern for corporate boards (Dahya and McConnell 2005; Johnson et al. 1996; Tian et al. 2011). However, it is not clear what determines the choice of a new CEO. We demonstrate that prospector-type firms have stronger incentives to appoint a CEO with high social capital while defender-type firms are less likely to do so. Furthermore, we show that prospectors on average improve firm value by making such an appointment decision. It would appear that this is a deliberate choice by prospector firms as the CEO networks allow them to obtain strategic information and resources needed for effective operations.

Second, this study adds to the corporate governance literature by demonstrating that good corporate governance can enhance the value-adding effect of CEO selection decisions; it is a possible means of constraining the costs associated with CEO social connections (Bruynseels and Cardinaels 2014; Cohen et al. 2014; Fracassi and Tate 2012; Hwang and Kim 2009; Larcker et al. 2013). Third, our study provides initial evidence that the value-adding effect of CEO social capital depends on firm-level factors, namely, the choice of strategy. We thus add to the “manager effects" literature by demonstrating the importance of CEO social capital as well as the 
effect of firm-level variables, namely strategy and corporate governance, on performance outcomes. $^{7}$

In the following section, we develop our hypotheses. This is followed by a description of our research design, results of our analysis, and concluding comments.

\section{Hypotheses development}

\section{Firm strategy and CEO selection}

We predict that the strategy of a firm will determine whether to appoint a CEO with high social capital. The accounting literature has for some time been interested in how strategic priorities influence management control choices, such as performance measurement and compensation design (see, e.g., Balsam et al. 2011; Ittner and Larcker 1997, 1998). More recent research examines selection and recruitment as a deliberate control design choice (Abernethy, Dekker, and Schultz 2015; Campbell 2012). The literature on CEO turnover and succession planning mainly focuses on drivers or performance consequences of CEO turnover (Coughlan and Schmidt 1985; Engel et al. 2003; Murphy 1999; Parrino 1997) and there has been limited attention paid to the determinants of CEO selection. Selection decisions require a firm to decide on what type of individuals will fit the requirements of the firm at a particular point in time (Allgood and Farrell 2003). When appointing a new CEO, the board's first task is to make a

\footnotetext{
${ }^{7}$ There is a debate in the "manager effects" literature as to whether it is a "manager effect" or a firm-effect. However, it has been difficult to separate out the different effects (see Abernethy and Wallis 2018 for a review of the literature). Similarly, some have cast doubt on the importance of social capital on firm value as the empirical models typically used in prior research have not been able to separate the impact of CEO social capital on firm value from the effects of firm-level characteristics (Tian et al. 2011). While using a CEO change setting may help tease out manager effects from firm-level variables (Fee et al. 2013), we still find significant firm-effects on firm performance (i.e., strategic priorities and corporate governance structure).
} 
"forecast of the future environment facing the corporation, an assessment of the degree and rate of change that will be required to cope with that environment, and an identification of the skills, experience, and foresight required of the next CEO” (Vancil 1987, 27).

It is reasonable to assume that the board will appoint a CEO with the traits and characteristics necessary to manage in the firm's environment. ${ }^{8}$ We predict that a prospector-type firm has incentives to appoint a CEO with high social capital. Prospector-type firms seek to be responsive to changes in market demand; it is a "prospector" in the sense that it wants to be first in the market for new products and services. It is these types of priorities that create greater levels of uncertainty for prospector-type firms than defender-type firms that choose to pursue a narrow and stable product focus (Bentley et al. 2013; Indjejikian 1999; Ittner et al. 2003; Prendergast 1999). ${ }^{9}$ A CEO with strong external networks (i.e., high social capital) is able to access information and resources that will be critical in mitigating the effects of uncertainty arising from a firm's choice of strategy. As Thompson (1967) long ago argued, uncertainty occurs when the amount of information available is less than the amount of information needed for decision making. One means of managing in an uncertain environment is to increase the

${ }^{8}$ For example, the prior literature recognizes that an individual's human capital, defined as context-specific knowledge and skills obtained through work experiences and manifested in reputation and prior performance, will be critical part of the selection process (see review by Crook et al. 2011; Erkens and Bonner 2013; Tian et al. 2011; Westphal and Zajac 1995). While often positively correlated, a CEO's social capital is as important as her human capital, if not more important in some contexts (Adler and Kwon 2002; Burt 2000; Coleman 1988; Geletkanycz and Boyd 2011).

${ }^{9}$ Evidence shows that firms adopt different approaches to performance measurement due to differences in uncertainty (Indjejikian 1999; Ittner et al. 2003; Prendergast 1999). Bentley et al. (2013) also argue that prospectortype firms experience much higher risks than defender-type firms and demonstrate how their different risk profiles associated with different strategic priorities lead to higher audit fees and greater opportunities to engage in financial misreporting. Their findings provide broad support for the idea that prospector-type firms face what is often described as a turbulent and uncertain environment and they have greater need to access information and resources in order to effectively manage in such an environment. 
amount of information available for decision making. Thus, when faced with uncertainty, a CEO's network will become increasingly important in obtaining the information needed to manage in this environment.

We expect that social capital enables a CEO to identify and exploit innovation opportunities (Faleye et al. 2014). For example, a CEO’s networks provide valuable access to “information and resources of important strategic utility” (Geletkanycz and Boyd 2011, 335). These networks increase the firm's ability to obtain scarce resources and receive favorable treatment in obtaining these resources (Akbas et al. 2016; Engelberg et al. 2012; Faleye et al. 2014; Pfeffer and Salancik 1978). Furthermore, CEOs with high social capital enhance the firm's legitimacy and status, which can have a significant impact in attracting key stakeholder groups, including employees, customers, suppliers, debtholders, and potential strategic partners (Engelberg et al. 2012, 2013; Fombrun 1996; Geletkanycz et al. 2001; Larcker et al. 2013). Given the rate of change that prospector firms typically face, firms also benefit from a CEO’s network as it facilitates expeditious access to firsthand information on other firms' (i.e., competitors') operational planning and business decisions (Geletkanycz and Boyd 2011; Geletkanycz and Hambrick 1997; Mizruchi 1996; Schoorman et al. 1981; Useem 1982). Taken together, social connections should enable a CEO to obtain the strategic information and resources needed to innovate and adapt to changes in the firm's product/market mix (Pfeffer 1991; Pfeffer and Salancik 1978). Thus, a CEO's connections provide an effective means of addressing the uncertainty (and the associated risk) inherent in a prospector-type strategy. 
We summarize our expectations as follows. Our hypotheses focus on prospector-type firms although our empirical model, for completeness, also includes defender-type firms. The first hypothesis predicts a positive relation between prospector-type strategy and the selection of a CEO with high social capital. We do not expect that defender-type firms will have the same incentives to appoint a CEO with high social capital and thus we do not predict any association. Our second hypothesis predicts that this selection choice will add value for prospector-type firms; we do not expect the same effect for defender-type firms.

HYPOTHESIS 1. There is a positive relation between prospector-type strategies and selection of a CEO with high social capital.

HYPOTHESIS 2. There is a positive relation between future firm performance and selection of a CEO with high social capital for firms pursuing prospector-type strategies.

\section{Does corporate governance mitigate potential agency losses for prospector-type firms who appoint CEOs with high social capital?}

While CEO networks can be beneficial to a firm, there is evidence that these networks enable CEOs to engage in opportunistic behaviors that are costly to the firm (Bebchuk and Fried 2003; Fracassi and Tate 2012; Malmendier and Tate 2009). Self-interested CEOs may strategically utilize their connections to promote their own interests rather than those of the firm (Bebchuk and Fried 2003). Indeed, the literature shows that CEOs with high social capital often accrue considerable power within the firm and leverage their status to influence their personal wealth, which in turn leads to performance-unrelated pay (Malmendier and Tate 2009), poor 
performance of the firm (El-Khatib et al. 2015; Malmendier and Tate 2009), and reduced reporting quality (Bruynseels and Cardinaels 2014; Krishnan et al. 2011). This evidence is in line with the power-based argument that boards acquiesce to CEOs with high social capital by granting them greater power and discretion within the organization (Bebchuk and Fried 2003; Hayward et al. 2004), which is detrimental to firm value (Abernethy, Kuang, and Qin 2015).

We recognize that there are costs and benefits of appointing a CEO with high social capital (Faleye et al. 2014; Larcker et al. 2016; Malmendier and Tate 2009; Useem 1982). We predict that prospector firms that appoint CEOs with high social capital perform better when there is good corporate governance in place, as strong corporate governance can be an effective mechanism in constraining managerial opportunism (Bebchuk and Fried 2003, 2004; Cotter et al. 1997; Gordon 2007). While good corporate governance is important for all firms, we examine its role in reducing the agency costs associated with CEOs with high social capital. Prospector-type firms can be more vulnerable to these costs as they have incentives to appoint CEOs with high social capital, that is, they recognize the benefits of making these appointments ( $\mathrm{H} 1$ and $\mathrm{H} 2)$. We thus expect that good corporate governance will be particularly important for firms pursuing prospector-type strategies. Hypothesis 3 summarizes our expectation:

HYPOTHESIS 3. Good corporate governance enhances the value-adding effect of CEO social capital for prospector-type firms.

\section{Some additional questions}


The premise underpinning our hypotheses is that CEOs with social capital will use their connections to exploit investment opportunities. We test this assumption by examining the association between CEO social capital and their investment preferences. This also allows us to contribute to the management literature that proposes a number of ways in which CEO networks can add value and yet there is limited documented evidence as to the types of decisions CEOs with high social capital make (Carpenter et al. 2001; Geletkanycz et al. 2001; Tian et al. 2011; Uzzi 1997). ${ }^{10}$

Second, we explore whether prospector-type firms place different levels of importance on different types of CEO social connections. Social network research shows that different types of social connections (such as employment ties vs. friendship ties) perform different functions and are activated by different situations (e.g., Gibbons 2004; Saint-Charles and Mongeau 2009). ${ }^{11}$ We are interested to find out whether prospector firms weigh the types of social ties differently when appointing a new CEO. Third, we seek to understand whether equity incentives can serve as a bonding mechanism to mitigate potential agency losses when firms appoint a CEO with high social capital. It has long been argued that profit and risk-sharing through incentive contracting can address agency problems (Fama and Jensen 1983; Milgrom and Roberts 1992). We assess

\footnotetext{
${ }^{10}$ The finance literature suggests that a CEO's personal connections to managers or directors in other firms can alleviate the CEO's risk aversion in investment decisions and predicts greater investment in innovation-type activities (Akbas et al. 2016; Faleye et al. 2014; Geletkanycz et al. 2001; Kilduff and Tsai 2003).

${ }^{11}$ For example, individuals rely on employment networks to obtain operational and strategic information (Gibbons 2004; Saint-Charles and Mongeau 2009). In comparison, friendship networks that are less visible, involve more intimate communication, and encourage the sharing of information and ideas about non-conventional and controversial issues (Bruynseels and Cardinaels 2014; Gibbons 2004; Saint-Charles and Mongeau 2009).
} 
whether equity incentives mitigate the potential agency costs associated with CEO social capital and, in turn, enhance the value-adding effect of CEO social capital.

\section{Research design and data description}

\section{Data sources and sample description}

To construct our CEO succession sample, we select all cases of CEO succession available from BoardEx Core Reports obtained in January 2014. We identified 1,645 instances of CEO succession between 2000 and 2013. We retrieved financial data from COMPUSTAT, CEO compensation data from ExecuComp, and stock price information from the Center for Research in Security Prices (CRSP); after merging, our sample reduced to 1,302 observations. We further obtained analyst information from I/B/E/S. Institutional ownership is from Thomson Reuters and blockholder ownership from Incentive Lab. After dropping observations with missing values, our final sample consists of 1,150 cases of CEO succession. Table 1 describes our sample selection procedure and presents the sample distribution over the investigation period. The frequency of CEO turnover stays flat in our investigation period, although we observe more turnover cases in some years. $^{12}$

\section{Variables of interest}

Firm strategy

We construct factor scores to capture a firm’s strategic priorities. Following the literature, we include six items, namely the ratio of $R \& D$ to sales $(R \& D)$ for a firm's propensity to search

\footnotetext{
${ }^{12}$ The low frequency of CEO turnover in 2000 and 2013 is likely due to the coverage of BoardEx. Dropping 2000's or 2013's observations does not change our main inferences.
} 
for new projects, the ratio of SG\&A to sales $(S G \& A)$ to reflect the firm's focus on exploiting new products and services, the ratio of sales to the cost of goods sold (MARGIN) for its ability to charge a higher price premium, the ratio of property, plant, and equipment to total assets ( $P P E)$ to capture a firm's capital intensity, the ratio of the number of employees to total assets (EMP) for labor intensity, and the ratio of sales to capital expenditures (SALECAPEX) for asset efficiency (Balsam et al. 2011; Bentley et al. 2013; Berman et al. 1999; Ittner et al. 1997; Nair and Filer 2003). $R \& D, S G \& A$, and MARGIN closely relate to prospector-type strategies, while PPE, EMP, and SALECAPEX represent dimensions of defender-type strategies (Balsam et al. 2011; Bentley et al. 2013). To capture a firm's long-term strategic orientation, we compute the mean for each of the six dimensions over five years prior to CEO succession (from year $t-5$ till year $t-1)$.

We employ principal component analysis to construct proxies for prospector-type and defender-type strategies. As expected, we find that the six items load on two factors: $S G \& A$, $R \& D$, and MARGIN all load on the first factor with factor loadings above 0.82, while PPE, EMP, and SALECAPEX load on the second factor and their factor loadings range from 0.50 to 0.95 . Then, we create two factor scores based on these factor loadings; we refer to the first factor as PROSPECTOR and the second factor as DEFENDER ${ }^{13}$

\section{CEO social capital}

\footnotetext{
${ }^{13}$ We capture prospector-type and defender-type strategies using two separate factor scores as this method allows for firms pursuing mixed strategies or ambidextrous firms. The value of the two composite measures increases with the level of the strategy they represent. Our method also enables us to develop unidimensional constructs while allowing for the relative importance of each item to be captured in the factor score.
} 
We follow prior research in constructing our measure of social capital (CEOTIES). We retrieve information on CEO and board director connections from BoardEx. The database provides detailed information on the education backgrounds, employment histories, and past and current membership in social organizations of top management and board directors (see, e.g., Bruynseels and Cardinaels 2014; Javakhadze et al. 2016). ${ }^{14}$ We measure a new CEO’s social capital by counting the number of her connections to external organizations, based on over 1.6 million records of top executives’ and directors' employment, education, and other activities (e.g., such as golf clubs, sports activities, charities, volunteer groups, etc.) covered by BoardEx. To ensure that we capture the incremental social capital of a new CEO, we excluded the overlapping ties through which the new CEO and the old CEO or current board members are connected to an external organization. ${ }^{15}$ This approach allows us to capture the new CEO's unique social capital at the time of her appointment. Table 2 reports the descriptive statistics of

\footnotetext{
${ }^{14}$ The database compiles information from public resources, including annual reports, media coverage, analysts' reports, etc. However, we admit that observed interpersonal relationships might have both type I and type II errors. As a practical matter, BoardEx does not list the start and end dates for many casual activities in the Core Reports we acquired. We follow the prior literature and remove the date restriction (Bruynseels and Cardinaels 2014). Our results stay robust when we only include dated social relationships. When defining alma mater relationships we check whether individuals received diplomas from the same institutes. We also check the robustness of our findings to adding a constraint that individuals have overlapping study periods, and obtain consistent results.

${ }^{15}$ We focus on CEOs' connections to external organizations and count the number of external organizations a CEO directly connects to (i.e., what social network theory would refer to as a one-mode network). Our measure is analogous to the degree measure of point centrality in the social network literature (Granovetter 1973). For example, Laurence Dickerson was appointed as its next CEO at Diamond Offshore Drilling Inc. in 2008. Upon the appointment, Laurence Dickerson had seven ties unique to the board directors' and the outgoing CEO's, among which four were established from employment history (Global Industries Ltd., Joint Ocean Commission Initiative, U.S. Commission on Ocean Policy, and Ernst \& Young Inc.) and three from other social activities (Consortium for Ocean Leadership, International Association of Drilling Contractors, and National Ocean Industries Association). As another example, Michael Bonney became the new CEO of Cubist Pharmaceuticals Inc. in 2003. At the appointment, he had four unique ties compared to directors and the old CEO: two established from past employment (Biogen Inc. and Zeneca Pharmaceuticals Inc.) and the other two from social activities (Bates College and Beth Israel Deaconess Medical Center).
} 
variables used in our main analyses. On average, a new CEO has about 10 social connections that are different from those of her predecessor's and board directors' social ties.

We take particular care to demonstrate the construct validity of CEO social capital. First, we examine the predictive validity of CEO social capital by testing its relation with CEO pay given prior research predicts a positive relation (Geletkanycz et al. 2001; Liu 2011). ${ }^{16}$ We find that CEOs with greater social capital indeed receive higher compensation in total pay, salary, and bonuses. In another validity test, we check whether our CEO social capital variable is positively related to the CEO’s human capital, as shown in the prior literature (Erkens and Bonner 2013; Tian et al. 2011; Westphal and Zajac 1995). We find that a CEO’s human capital and social capital are significantly and positively correlated (see Table 3), consistent with the results of our multivariate regression analysis (see Table 4). We also assess the relation of CEO social capital with CEO ability using the Demerjian, Lev, and McVay (2012) measure. While the Demerjian et al.'s measure has been used repeatedly in the 'manager effects' literature, it has several limitations (see Abernethy and Wallis 2018). It is difficult to use this measure as an individual level variable because by construction it captures 'management efficiency' that includes other senior management within the firm. ${ }^{17}$ Nevertheless, we assess its relation with CEO social

\footnotetext{
${ }^{16}$ We regress CEO total pay, as well as various pay components, using three-year average compensation after appointment available from the ExecuComp database, on CEOTIES and a host of control variables, including firm performance, CEO and firm characteristics, and corporate governance proxies (Chang et al. 2016; Coles et al. 2006; Core and Guay 2002). Due to zero pay cases of bonus and options, our compensation data are truncated on the lefthand-side. We employ Tobit models to estimate bonus and options (Tobin 1958). We employ OLS models when total pay and salary are used as the dependent variable.

${ }^{17}$ Demerijian et al. (2012) also acknowledge limitations of their measure; namely, that there is potential for different accounting treatments and imperfect industry classifications to affect their measure. It is also possible that firm-level characteristics could be affected by decisions made by top management team, in which case this approach
} 
capital and not surprisingly find no significant correlation. We also run a robustness test where we control for Demerjian et al.'s (2012) managerial ability measure in our regression models, which allows us to demonstrate that CEO social capital is not simply capturing CEO ability. The results are discussed in robustness tests. ${ }^{18}$

We also test the convergent validity of the measure by examining the correlation with items that capture business complexity. Ceteris paribus, we would expect to find CEOs with high social capital in more complex firms as such firms have a stronger demand for strategic information and resources (Bushman et al. 2004). We use firm size, firm age, and the number of business segments as proxies for firm complexity (e.g., Ashbaugh-Skaife et al. 2008; Ge and McVay 2005). Tables 3 and 4 show that the proxies for firm complexity are significantly correlated (or related) with higher CEO social capital, providing further support for the validity of our CEO social capital measure. ${ }^{19}$ In addition, we perform placebo tests and replace CEO social capital with a CFO social capital measure. Our findings suggest that our CEO social capital measure does not merely represent a firm-level effect as CFO social ties do not yield the same results.

Firm performance

understates the individual manager effects. That is, Demerjian et al.'s (2012) measure is clearly intended to capture all manager effects on firm efficiency, rather than just the CEO effects, which appears to be the authors' intention.

${ }^{18}$ We choose not to include Demerjian et al.'s (2012) managerial ability measure in our main regressions, as the inclusion of this measure causes a 14 percent reduction of our sample size while our results stay inferentially unchanged.

${ }^{19}$ While we use complexity to demonstrate the convergent validity of our CEO social capital variable, we also control for firm complexity in our model of the determinants of CEO selection, so that we can demonstrate the incremental explanatory power of strategy. 
We use Tobin's Q and ROA to measure market and accounting indicators of firm performance, respectively (Kale et al. 2009; McDonald et al. 2008; Mehran 1995; Vafeas 1999). Tobin's $Q(Q)$ serves as a proxy for firm value, defined as the ratio of the market value of assets in place over the replacement cost of these assets (Bebchuk et al. 2009; Bebchuk et al. 2013; Coles et al. 2008; Gompers et al. 2003; Yermack 1996). Following the prior research, ROA $(R O A)$ is measured as net income scaled by total assets and used as an indicator of how efficiently a firm is using its assets to yield accounting earnings (Bowen et al. 2008; Core et al. 1999). Furthermore, we measure both $Q$ and $R O A$ averaged over a three-year period after the CEO appointment (from year $t+1$ to year $t+3$ ) to mitigate the influence of possible turbulence in share prices, the recognition lag, and the write-offs (i.e., the big bath effect) that occur immediately after CEO turnover (Daily et al. 2000; Murphy and Zimmerman 1993; Shen and Cannella 2002). We follow the literature and define the first year of a CEO's employment as the first year the CEO has held the position for at least six months (Kuang et al. 2014).

The descriptive statistics in Table 2 show that the mean of $Q$ is about two, indicating that the market value of assets for an average firm is about two times the replacement value of its assets. The average of $R O A$ is -0.055 , consistent with the prior evidence that firms often report losses after a CEO change (Farrell and Whidbee 2003; Shen and Cannella 2003).

\section{Corporate governance}

We construct a composite measure, based on the prior literature, to capture corporate governance quality. Similar to Abernethy, Kuang, and Qin (2015), we use principal component 
analysis to develop a composite variable $(C G)$ with its value increasing with the quality of corporate governance. We include CEO duality, board size, percentage of independent directors on board, institutional ownership, and largest blockholder ownership to measure related but distinct dimensions of corporate governance. CEO duality and board size are included, as the corporate governance literature shows that they capture the concentration of decision making rights in one person and lack of cohesive board decisions, respectively (e.g., Bebchuk et al. 2009; Gompers et al. 2003; Yermack 1996), while percentage of independent board members, institutional ownership, and blockholder ownership proxy for board independence and other countervailing forces argued to discipline a CEO (e.g., Cremers and Nair 2005; Hartzell and Starks 2003; Hermalin and Weisbach 1998; Weisbach 1988). Untabulated results show that a CEO also chairs the board in 51 percent of our sample firms. On average, a corporate board consists of 11 board members, 75 percent of whom are independent, and the largest blockholder owns nearly 18 percent of company shares.

\section{Empirical models}

We first assess the association between firm strategy and CEO social capital using the following OLS model:

$$
\begin{aligned}
& \text { CEO Social Capital }=\alpha_{0}+\alpha_{1} \text { PROSPECTOR }+\alpha_{2} \text { DEFENDER } \\
& +\alpha_{3} \text { Corporate Governance }+ \text { Control Variables }+\varepsilon
\end{aligned}
$$


In Hypothesis 1, we expect that prospector-type firms have incentives to appoint CEOs with higher social capital, which suggests a significantly positive $\alpha_{1}$ in model (1). For completeness, DEFENDER and Corporate Governance are also included in the model.

There is an array of firm-level control variables included in model (1), including a firm's average monthly stock returns (RETPRE24M), volatility over 24 months prior to CEO appointment (VOLPRE24M) (Clayton et al. 2005; Chang et al. 2010; Francis et al. 2008), firm complexity as measured by firm size in total assets (LNTA), and the number of business segments in which the firm operates (SEGMENT) (Ashbaugh-Skaife et al. 2008; Ge and McVay 2005; Houghton et al. 2009), and the number of years a firm has been listed (FIRMAGE) (Lester et al. 2003; Miller and Friesen 1984). At the CEO level, we control for a CEO’s human capital as measured by the number of awards and certificates the CEO has received prior to her appointment (HUMANCAP) (Carpenter et al. 2001; Erkens and Bonner 2013; Johnson et al. 2013); the age of a CEO (CEOAGE); whether the new CEO is appointed from outside the firm (OUTSIDER); ${ }^{20}$ whether the CEO has a U.S. nationality (US) (Daily et al. 2000; Zhang and Rajagopalan 2004); and an indicator (CEOBOARDTIES) that equals one if the new CEO is socially connected with board directors via overlapping employment, education, and other

\footnotetext{
${ }^{20}$ The value enhancement effect of social capital may hold for both outside and inside CEO hiring. Air-dropped CEOs are new to firms' upper echelons and obviously possess connections not yet included in the firms' current relationships. For internally groomed CEOs, they are positioned to embrace a new range of opportunities after the appointment to utilize the full potential of their connections. Different levels of skills and expertise are required at a lower-level position compared to those required at CEO level. Individuals thus have less incentive to fully realize the potential of their social networks before being promoted to the CEO position (Gibbons and Murphy 1992). Shen and Cannella (2003) find that shareholders react positively to the promotion of a previously named "heir apparent" to CEO, suggesting that it is entirely possible that inside successors have not yet reached the full potential of their social connections before promotion.
} 
activities outside the current firm, and zero otherwise (Tian et al. 2011). Further, we include an indicator (GFC) for years during or after the 2007 Global Financial Crisis to control for a possible time trend in CEO turnover. A dummy is also included that equals one if a sample firm is from the manufacturing industry (MANUFACTURING) (Kuang et al. 2014).

To test Hypothesis 2, predicting that the interaction between prospector-type firms and CEO social capital will have a significantly positive effect on firm performance, we use the OLS model described below and expect $\beta_{4}$ to be positive in model (2). For completeness, we also include an interaction between CEO social capital and defender-type firms, but we do not expect a significant $\beta_{5}$ :
Firm Performance $=\beta_{0}+\beta_{1}$ CEO Social Capital $+\beta_{2}$ PROSPECTOR $+\beta_{3}$ DEFENDER + $\beta_{4}$ CEO Social Capital $\times$ PROSPECTOR $+\beta_{5}$ CEO Social Capital $\times$ DEFENDER + $\beta_{6}$ Corporate Governance + Control Variables $+\varepsilon$

Hypothesis 3 predicts that the value-adding effect of CEO social capital for prospectortype firms is stronger with good corporate governance. To test H3, we adapt model (2) by including a three-way interaction term (i.e., CEO Social Capital $\times P R O S P E C T O R \times$ Corporate Governance). Note that our focus is on prospector-type firms and whether good corporate governance can mitigate some of the agency costs that arise when these firms appoint a CEO with high social capital. We predict that the value-adding effect of CEO social capital is enhanced for prospectors with good corporate governance, and hence expect $\gamma_{8}$ to be 
significantly positive in model (3). For completeness, we include a similarly constructed interaction term for defenders; again, we do not expect the coefficient to be significant. ${ }^{21}$
Firm Performance $=\gamma_{0}+\gamma_{1}$ CEO Social Capital $+\gamma_{2}$ PROSPECTOR $+\gamma_{3}$ DEFENDER + $\gamma_{4}$ CEO Social Capital $\times$ PROSPECTOR $+\gamma_{5}$ CEO Social Capital $\times$ DEFENDER + $\gamma_{6}$ Corporate Governance $+\gamma_{7}$ CEO Social Capital $\times$ Corporate Governance + $\gamma_{8}$ CEO Social Capital $\times$ PROSPECTOR $\times$ Corporate Governance + $\gamma_{9}$ CEO Social Capital $\times$ DEFENDER $\times$ Corporate Governance + Control Variables $+\varepsilon$

The inclusion of control variables in models (2) and (3) is based on prior research (Daske et al. 2008; Leuz 2003; Tian et al. 2011). Specifically, we include the same array of controls included in model (1) plus sales growth (SALESGROWTH) for growth opportunities and analyst following (NUMANALYST) for information environment (Lang et al. 2003; Leuz 2003). We winsorize all continuous variables at both the top and bottom one percent to limit the influence of outliers. Industry- (defined by first two digits in a SIC code) and year-fixed effects are included in all models. The Appendix summarizes the variable definitions. Further, we estimate the models with standard errors White-Huber adjusted for heteroskedasticity (Greene 2012; Huber 1967; White 1980).

Table 2 provides the descriptive statistics for the variables. The summary statistics are in line with the prior literature (see, e.g., Black et al. 2006; Kuang et al. 2014; Yermack 1996). Table 3 reports the correlation matrix. We find that CEO social capital is significantly and negatively correlated with defender-type strategies and firm performance prior to appointments.

\footnotetext{
${ }^{21}$ It is worth-noting that we have to drop two-way interactions between strategy and corporate governance due to multicollinearity.
} 
Our measures of firm performance (i.e., $Q$ and $R O A$ ) are significantly and positively correlated, suggesting that they capture the same underlying concept. Firm performance has a significantly positive correlation with stock returns before CEO turnover, corporate governance, and sales growth, whereas there is a significantly negative correlation between firm performance and firm size, number of segments, as well as the indicator for manufacturing industry. The correlations among control variables are generally in line with the literature and do not raise multicollinearity concerns, as the variance inflation factor (VIF) in all regressions are less than two, well below the cutoff threshold of 10 to indicate multicollinearity (Kennedy 1992).

\section{Empirical results}

\section{Firm strategy and CEO social capital (Tests of $\mathrm{H} 1$ and $\mathrm{H} 2$ )}

The results relating to the association between firm strategy and CEO selection are summarized in column 1, Table 4. The coefficient on PROSPECTOR is significantly positive (0.821; $p$-value $<0.01)$, consistent with $\mathrm{H} 1$ that prospector-type firms have greater incentives to appoint a CEO with high social capital. In terms of economic significance, a one standard deviation increase in PROSPECTOR is associated with approximately one additional required social connection of a new CEO unique to the old CEO and the board, equivalent to 11.8 percent of the standard deviation in CEOTIES, which accounts for a non-trivial amount of variation in CEO social capital. ${ }^{22}$ The coefficient on DEFENDER is not significant in column 1, consistent with the idea that firms pursuing defender-type strategies do not necessarily seek to appoint

\footnotetext{
${ }^{22} 0.821 \times 1.000=0.821$, and $0.821 \times 1.000 \div 6.960=0.118$, where 0.821 is the coefficient on PROSPECTOR, 1.000 is the standard deviation of PROSPECTOR, and 6.960 is the standard deviation of CEOTIES.
} 
CEOs with high social capital. It is interesting to note that corporate governance quality does not exhibit significant power in influencing the choice of a CEO with high social capital. ${ }^{23}$ Taken together, our results indicate that strategy is an important driver in the decision to appoint a CEO with high social capital, while there appears to be no direct effect of corporate governance on this decision.

Turning to the control variables, we find that large (LNTA) and complex firms (SEGMENT) tend to hire CEOs with greater connectedness (Festré 2002; Schumpeter 1939). Further, the coefficient on CEOBOARDTIES is significant and positive, in line with prior evidence that a CEO's social connections inside and outside the company are often correlated (Tian et al. 2011). HUMANCAP is significant and positive, suggesting that a CEO's human capital is indeed positively associated with her social capital (Adler and Kwon 2002; Johnson et al. 2013). We also find that CEOs hired from outside and those who are older in age tend to have higher social capital.

We predict that firms that are pursuing a prospector-type strategy and appoint CEOs with high social capital will perform better than those that do not match the choice of CEO with the strategy (see H2). We test our expectation using model (2) and report results in columns 1 and 3 of panel A, Table 5, where the dependent variable measures firm performance by average $R O A$ and $Q$, respectively, from $t+1$ to $t+3$ after CEO appointment. Our test variable is the interaction term between firm strategy and CEO social capital. The significantly positive

\footnotetext{
${ }^{23}$ We also include a term to capture any plausible interaction between corporate governance and strategy on CEO selection but find no significant effect (see column 2, Table 4).
} 
coefficients on CEOTIES $\times$ PROSPECTOR ( $p$-value $<0.05)$ in both columns 1 and 3 support our expectation that the performance of prospector firms, on average, increases when CEOs with high social capital are appointed. The economic significance of the joint effect of social capital and firm strategy is also evident. Specifically, in column 1 where the dependent variable is $R O A$, the coefficients of CEOTIES and CEOTIES $\times$ PROSPECTOR are both 0.001 . Hence, for a one standard deviation increase in PROSPECTOR from the sample mean, the effect of CEO social capital on ROA is doubled. ${ }^{24}$ In contrast, the coefficient on CEOTIES $\times$ DEFENDER is not significant. The results on control variables are consistent with the prior literature. Firms experiencing volatile market returns before CEO turnover (VOLPRE24M) are associated with poor performance (Farrell and Whidbee 2003; Fee and Hadlock 2004). Firm size (LNTA) has a significantly negative association with firm performance (Black et al. 2006; Lang and Stulz 1994). Firms with higher sales growth or followed by more analysts tend to have better performance (Barth et al. 2008; Lang et al. 2003). Further, performance is relatively weak in firms appointing an older CEO and after the Global Financial Crisis.

\section{Does good corporate governance strengthen the impact of $\mathrm{CEO}$ social capital on firm value in prospector firms? (Test of $\mathrm{H} 3$ )}

Our results indicate that prospector firms that appoint CEOs with high social capital have improved performance. We then turn our attention to the effect of corporate governance for prospector firms (see H3) as these firms are most vulnerable to the agency costs that might arise

\footnotetext{
${ }^{24}$ When $Q$ is the dependent variable (see column 3, Table 5), the coefficients on CEOTIES and CEOTIES $\times$ PROSPECTOR are 0.013 and 0.019 , respectively. For a one standard deviation increase in $P R O S P E C T O R$ from the sample mean, the effect of CEO social capital on $Q$ is roughly two and a half times larger.
} 
given the importance of CEO social capital for these firms. ${ }^{25}$ The regression results of model (3) are summarized in columns 2 and 4 of panel A, Table 5, where there is a significant and positive coefficient on the three-way interaction CEOTIES $\times P R O S P E C T O R \times C G$ for both $R O A$ and $Q$. These results support our expectation that prospector firms who appoint a CEO with high social capital perform better when good corporate governance practices are in place. ${ }^{26}$

We next follow a Heckman two-stage procedure to address the non-randomness in CEO selection (Bertrand and Schoar 2003; Fee et al. 2013). ${ }^{27}$ In the first-stage model, the dependent variable (HI_CEOTIES) is an indicator variable equal to one if a new CEO’s social capital is in the top quartile of our sample, and zero otherwise; we fit a probit model to predict the binary decision to appoint a well-connected CEO. Apart from the control variables as described in model (1), we add an exclusive variable (SUNLAND) that measures the climate of headquarters' location (i.e., an indicator equals one if the headquarters of a firm is located in a city with annual sunny days no less than 100 days, and zero otherwise); ${ }^{28}$ it is possible that firms located in an area that is meteorologically more appealing are advantageous in attracting well-connected

\footnotetext{
${ }^{25}$ In untabulated results, we also find that the interaction between CEOTIES and corporate governance is positive and significant, indicating the importance of good governance in mitigating the effects of CEO social capital, regardless of the strategy pursued.

${ }^{26}$ We also split our sample into good vs. poor corporate governance groups based upon whether the value of $C G$ is in the top or bottom quintile of the sample. Then we re-run model (2) in two groups, respectively. Untabulated reports show that the coefficient on CEOTIES $\times$ PROSPECTOR is significantly positive in the good corporate governance group, while it is statistically less positive in the poor corporate governance group.

${ }^{27}$ In our regression models, we include a host of economic determinants of CEO social capital and hence partially address the selection bias in the firm performance model. However, the non-randomness in CEO selection may also come from unobservable factors that may drive our results (Lennox et al. 2012); that is, factors other than strategy and those we include as control variables.

${ }^{28}$ Following Lennox et al. (2012), we apply an "exclusion restriction;" that is, we add a variable in the first-stage Heckman model but exclude it from the second-stage. For our excluded variable to yield a powerful test for selection bias, it needs to be an important determinant of CEO social capital but have no direct impact on firm performance.
} 
CEOs (Fee et al. 2013; Yonker 2016), ${ }^{29}$ while we have no good reason to expect that a firm headquarters' climate will directly impact firm value. Indeed, in Table 3 and column 3 of Table 4 we find that SUNLAND has a significantly positive association with a firm's propensity to appoint a CEO with high social capital ( $p$-value < 0.05) while its correlation with firm performance is not significant. Next, we compute an inverse Mills' ratio (MILLS) based on the stage-one regression with results reported in column 3 of Table 4 . We then include MILLS in our stage-two firm performance models. The results are reported in panel B of Table 5, showing that our prior findings continue to hold after controlling for "selection on unobservables" (Lennox et al. 2012, 612).

\footnotetext{
${ }^{29}$ Labor economists argue that geographically attractive firms, such as those located in cities with sunny weather, have a deeper pool from which to select their CEOs and thus a better chance to select more suitable CEOs when the pool of choice is deep (Yonker 2016). Following Fee et al. (2013), we use NOAA National Weather Data and construct SUNLAND.
} 


\section{Additional analysis}

How does CEO social capital influence investment decisions?

The management and finance literatures suggest that CEO social capital significantly influences CEOs' investment preferences given that these CEOs can utilize their external networks to access information and resources (Akbas et al. 2016; Faleye et al. 2014; Geletkanycz et al. 2001; Kilduff and Tsai 2003). Our data enables us to explore whether the variation in expenditure preferences can be explained by a CEO's social capital. We do not condition this analysis on a firm's strategy, as all CEOs with high social capital can use their social networks when making their investment choices. We use R\&D and SG\&A expenditures to assess the impact of CEO social capital on these decisions, as both expenditure decisions require additional resources and external networks can be valuable in the process (Balsam et al. 2011; Ittner et al. 1997; Nair and Filer 2003). Table 6 reports the results. We find that a new CEO’s social capital is significantly and positively associated with both SG\&A and R\&D spending (except for column 3). We also find that the interaction between corporate governance and social capital (i.e., CEOTIES $\times C G$ ) is significantly positive, indicating that these types of expenditure increase when good corporate governance is in place. ${ }^{30}$ These results reinforce the underpinning assumptions concerning CEO social capital (see H1) and our expectation concerning the role of good corporate governance (see H3).

\footnotetext{
${ }^{30}$ We also assess whether corporate governance can moderate the effect of social capital on one measure of innovation outcomes, namely the number of patents. Untabulated results indicate a significantly positive coefficient on the interaction between CEOTIES and CG, providing additional support for the importance of good corporate governance when firms appoint CEOs with high social capital.
} 


\section{Types of CEO connections}

We investigate the association between a firm's strategy and the different types of CEO connections. Specifically, we break down the CEO social ties into connections established via work-related activities and connections established via friendship activities (e.g., alumni, clubs, charities, volunteer organizations) and re-run model (1) using the two types of ties as the dependent variable, respectively. We treat the two regressions as seemingly unrelated to accommodate the embeddedness of social connections (Greene 2012; Larcker et al. 2013; Kilduff and Tsai 2003). Our results, untabulated, show that prospector-type firms are inclined to appoint CEOs with widespread connections formed through professional networks and through informal friendship networks ${ }^{31}$ while firms following a defender strategy will not necessarily place significant importance on either type of social connections when appointing a CEO.

\section{Bonding mechanism}

Next, we examine whether CEO equity incentives work effectively as a bonding mechanism and moderate the impact of CEO social capital on firm performance. We follow the literature and use equity delta to capture the sensitivity of CEO wealth to firm value changes (Core et al. 1999; Coles et al. 2006; Core and Guay 2002). ${ }^{32}$ We adjust model (2) by including equity delta and its interaction with social capital. The results (untabulated) indicate that the equity delta exhibits no statistically significant power in explaining firm performance, neither

\footnotetext{
${ }^{31}$ We do not find significant differences in the coefficients between two types of ties for prospector firms.

${ }^{32}$ In our sample, on average a new CEO's equity delta is 586,000; that is, an average CEO's wealth in the firm increases by US $\$ 586,000$ for each 1 percent increase in stock price of the firm, comparable to the prior literature (Bergstresser and Philippon 2006; Gabaix and Landier 2008).
} 
does its interaction with CEO social capital, consistent with mixed evidence of equity incentives in the prior literature (e.g., Cheng and Warfield 2005; Burns and Kedia 2006). ${ }^{33}$ We next run a partitioned sample analysis and examine the joint effect of social capital and equity incentives on firm performance in good and poor corporate governance subsamples, respectively. ${ }^{34}$ We find that the bonding mechanism based on equity incentives comes into play (i.e., a significantly positive joint effect) when good corporate governance is in place (Armstrong et al. 2013; Landsman et al. 2007). The interaction term is significantly negative in cases of poor corporate governance, suggesting that equity incentives, in the absence of strong corporate governance, could have an adverse effect on firm value.

\section{Market reaction to CEO appointments}

We run an additional test of our theoretical predictions by assessing how the securities market reacts when prospector-type firms appoint a new CEO with high social capital. We employ an event study method and examine market reaction to the announcement of CEO change. ${ }^{35}$ We searched company press releases in LexisNexis by CEO name, company name, and year of CEO appointment, constraining that keywords, such as “CEO,” "executive,"

\footnotetext{
${ }^{33}$ For example, the rent extraction argument of equity incentives considers executive compensation itself part of (instead of a remedy to) the agency problem (Bebchuk and Fried 2004, 2006). CEOs may "rig" incentive contracts, in which case we would not expect that the provision of equity incentives would increase the bonding of the CEO to the firm. Rather, it allows the CEO to extract rents from the firm (Abernethy, Kuang, and Qin 2015; Morse et al. 2011). Prior studies document that equity incentives are positively associated with earnings management (Bergstresser and Philippon 2006), misreporting (Armstrong et al. 2013), management fraud (Sen 2007), excessive risk-taking (Coles et al. 2006), and cost of debt (Shaw 2012), all of which have negative implications for firm value.

${ }^{34}$ Firms with good corporate governance are those with $C G$ in the top quintile of our sample and bad corporate governance firms are those with $C G$ in the bottom quintile.

${ }^{35}$ We estimate cumulative abnormal returns over a 3-day window $[-1,+1]$ surrounding the announcement date (Cannella and Lubatkin 1993; Shen and Cannella 2003), where abnormal returns are defined as raw returns minus value-weighted market returns (Henry and Leone 2016).
} 
"succession," "successor," "replacement," and "leader," appear within 20 words of the CEO's name. In this way, we obtained 1,038 CEO succession announcements with available announcement dates. After merging with CRSP stock market data on daily stock prices, our final sample for the event study reduces to 732 CEO successions. Our results, untabulated, indicate that surrounding the announcement date the market reacts positively to prospector firms appointing CEOs with high social capital, but negatively if firms pursuing defender strategies make a similar CEO selection. Furthermore, market reaction is more positive when a firm has installed good corporate governance.

\section{Robustness checks}

\section{Placebo tests}

We run several placebo tests to rule out alternative explanations (Bertrand and Schoar 2003; Roberts and Whited 2013). First, we replace firm performance measures in models (2) and (3) with a placebo dependent variable $-Q$ and $R O A$ measured one year prior to CEO succession. If the underlying driver is indeed the treatment effect; that is, the interaction between CEO social capital and prospector-type strategies (and corporate governance); we should not find any significance on the interaction terms in the placebo tests. Untabulated results show that it is indeed the case. A further concern is that our CEO social capital measure might be capturing a firm-wide effect. To address this concern, we replace CEO social capital with a CFO social capital measure (see, e.g., Jia et al. 2014). Consistent with the literature, we find that CFOs are less socially connected compared to CEOs (Erken and Bonner 2013). We replicate prior analysis 
and show that there is no significant effect that flows through using the CFO social capital measure. Hence, our prior findings are robust to the placebo tests.

\section{Alternative measures of firm strategy}

We use alternative measures of firm strategy to test our hypotheses. First, we shorten the period of measuring firm strategy and use only recent years (i.e., three years prior to CEO change from $t-3$ to $t-1)$. Furthermore, we consider the changes in strategies after CEO succession and measure the magnitude of the changes towards more prospector-type (defendertype). ${ }^{36}$ We further construct another set of strategy measures based on the mean values of the six strategy items over three (five) years after CEO turnover, i.e., from $t+1$ till $t+3$ (from $t+1$ till $t+5)$. We also use sales growth and sales growth volatility over the last five years as alternative measures of firm strategy as a firm’s strategic priorities might also be reflected in its growth and associated risk. In addition, the literature suggests that firms in pursuit of a prospector strategy may spend more on tangible assets rather than intangible projects such as R\&D (Dosi 1988; Kleinknecht et al. 2002; Santamaría et al. 2009). We thus construct another set of composite measures of strategies, excluding $R \& D$ from the constituents, and replicate prior analysis. In all cases, we obtain similar results (untabulated).

\section{Other moderating factors}

\footnotetext{
${ }^{36}$ We estimate PROSPECTOR and DEFFENDER both before and after the CEO appointment (i.e., using data from $t-3$ to $t-1$ and from $t+1$ to $t+3$ ) and take the change of PROSPECTOR and DEFFENDER after the appointment (relative to pre-appointment) to proxy for strategy change after CEO appointments.
} 
Although related, information environments and business complexity are conceptually distinct from strategy (Bloom and Michel 2002; Finkelstein et al. 1996). We investigate whether the information environment and business complexity moderates the relationship between CEO social capital and firm performance. Firms operating with greater complexity or poor information environment may have greater demand for a CEO with high social capital as CEO connectedness can help cope with business complexity (Ashbaugh-Skaife et al. 2008; Michel and Hambrick 1992). We interact CEOTIES with NUMANALYST, SEGMENT, and SALESGROWTH, and include into model (2), separately. Our results (untabulated) indicate that the interaction term has no significant power in explaining the variation in firm performance in any of these cases. However, we find that stock return volatility before CEO turnover (VOLPRE24M) significantly moderates the association between CEO social capital and firm value, such that CEO connectedness is more value-adding for firms with greater stock return volatility. This finding is consistent with the notion that stock return volatility may capture a firm's growth opportunities and reflect its uncertainty; in other words, it could be an alternative measure for a firm's strategic priorities.

\section{Other robustness tests}

We check the robustness of our results using several other tests. We collect information on the underlying cause of CEO change by reading through CEO succession press releases. Among the 1,038 cases of CEO succession announcement, 22 CEOs were dismissed due to 
unsatisfactory firm performance. ${ }^{37}$ We remove those 22 CEO turnover cases from our sample and replicate prior analysis. In another test, we exclude interim CEO cases (i.e., a CEO successor stays with the firm for no more than two years until the appointment of the next CEO). We also check the robustness of our findings by including an indicator for firms with multiple CEO turnovers during our investigation period. Our prior results continue to hold.

Further, we identify $121 \mathrm{COO}$ turnover cases that take place in the same year as CEO turnover. When excluding the concurrent $\mathrm{COO}$ turnover cases from the sample, we obtain inferentially consistent results. ${ }^{38}$ We also create a $\mathrm{COO}$ turnover indicator and find that including this variable into our models does not change our main inferences. Furthermore, we investigate the plausible changes in corporate governance after CEO appointments. We compare the composite corporate governance measure, as well as each of the individual components, between pre- and post-appointment periods $(t-1$ and $t)$. We find that the quality of corporate governance remains statistically unchanged after CEO appointments. We also exclude years with significant events, including the corporate scandals of 2000, the 2002/2003 SOX implementation, and the 2007 Global Financial Crisis. Our findings continue to hold in all of these tests.

Finally we run a model to address any concerns that our results are driven by CEO ability rather than CEO social capital. In the analysis of CEO pay, we do not find that CEO social

\footnotetext{
${ }^{37}$ The search for forced CEO turnover has both type I and type II errors. We expect the type I errors to be small as it is unlikely that firms would depict a planned CEO succession as dismissal, whereas it is not uncommon that firms may offer a dismissed CEO a graceful exit by framing it as a planned succession.

${ }^{38}$ Evidence shows that COOs oversee ongoing business, and a CEO may delegate operation and investment decisions to her COO (Marcel 2009). Thus, it is plausible that concurrent COO turnover rather than CEO turnover contributes to our findings.
} 
capital relates to significantly higher stock option compensation. According to the theoretical work of Arya and Mittendorf (2005), only a high-ability CEO will accept a contract that has high levels of stock options because such a CEO is willing to put her own reputation at risk to generate higher compensation. Our findings thus suggest that CEOTIES is less likely to be merely a proxy for CEO ability. To lend further credence to our primary findings, we follow Demerjian et al. (2012) and include in our regression models their measure of managerial ability as an additional control. ${ }^{39}$ Our untabulated results are consistent with the findings presented in Table 5.

\section{Conclusions}

Despite CEO selection being one of the most important decisions a firm makes, there is little research in the accounting literature that examines the determinants of CEO succession decisions. The key question that a board of directors responsible for this decision will ask is what type of individual will add the most value to the firm (Larcker et al. 2016). The purpose of this study is to shed some light on this question. We draw on the well-established literature documenting the importance of networks or what is often referred to as an individual's social capital. We argue that appointing a CEO with high social capital is particularly important for firms pursuing a prospector-type strategy, as the CEO is able to use her networks to effectively implement the firm's strategic priorities.

\footnotetext{
${ }^{39}$ A detailed description of Demerjian et al.'s (2012) managerial ability data is available at: http://faculty.washington.edu/pdemerj/data.html.
} 
The use of CEO succession enables us to focus on the new CEO's unique set of connections (relative to the outgoing CEO's and board members'). Our measure captures the “fresh” resources brought in by the new CEO and is less likely to have already been incorporated into firm-level characteristics, which gives us a better chance to attribute observed effects to CEO social capital. Our empirical findings indicate that firm strategy determines the importance of social capital when selecting a new CEO. More specifically, we show that prospector-type firms tend to appoint a CEO with high social capital. Furthermore, we find that this appointment choice has a value-adding effect. We also recognize that a CEO can use her social capital in ways that are detrimental to the firm, thereby creating a dilemma for those charged with selecting a new CEO. We find that good governance provides a means of reducing agency losses when prospector firms appoint a CEO with high social capital. In other words, firm value is enhanced by a combination of appointing a CEO with the right attributes to implement a firm's strategic priorities and ensuring that good corporate governance is in place. ${ }^{40}$

Our study may be subject to several limitations. First, our measure of CEO social capital focus on direct social ties, whereas the literature on social capital suggests that a person's strategic position in the network, including his/her indirect social relations, may also be informative in evaluating individual connectedness (Kilduff and Tsai 2003). We recognize that we may not capture the full breadth of CEOs' social networks. Nevertheless, studies show that

\footnotetext{
${ }^{40}$ It is interesting to note that, unlike strategic priorities, corporate governance structure does not appear to be the primary driver for the selection of high social capital CEOs, nor does it interact with strategy in determining CEO selection. However, our results show that strong corporate governance does add value to prospector-type firms that appoint a CEO with high social capital. Taken together, our findings suggest that prospector firms would benefit more if they also consider their governance structure at CEO selection decisions.
} 
direct and indirect ties are positively and highly correlated (Kuang and Lee 2017; Larcker at al. 2013) and thus, our results may provide useful insights for indirect social relations. Second, while our expectations are developed based on a theoretical framework and our results are consistent with our expectations, we acknowledge that we cannot fully establish causality. Third, we assume that it is a CEO's networks that help the firm identify operational opportunities, evaluate competitors' actions, and obtain strategic resources. In practice, CEOs may delegate some of these decisions to other senior management or make decisions jointly with the whole top management team. Therefore, future research could examine whether overall social capital of the top management team can improve decision making and firm value.

Despite these potential limitations, our tests provide evidence of when firms are more likely to appoint CEOs with high social capital and when these decisions are likely to enhance firm value. Our findings provide insights that could be useful to academics, practitioners, and regulators who are concerned with CEO succession. Overall, our findings are consistent with the proposition that appointing well-connected CEOs is important when a firm faces uncertainty, such as those pursuing prospector-type strategies (Bazerman and Schoorman 1983; Larcker at al. 2013; Schoorman et al. 1981). We also support those who are concerned with the costs associated with CEO social connections and demonstrate that these costs can be mitigated through good corporate governance. Lastly, although prior research suggests that managerial styles and personal traits are significant predictors of firms' performance outcomes, our findings indicate that corporate strategy may drive the selection of a CEO and, in turn, have an impact on 
firm performance. At a minimum, scholars wanting to examine the effect of CEO characteristics should consider the influence of firm strategy on CEO selection as strategic priorities may explain why firms appoint particular types of CEOs. 


\section{References}

Abernethy, M. A., H. C. Dekker, and A. K. D. Schulz. 2015. Are employee selection and incentive contracts complements or substitutes? Journal of Accounting Research 53 (4): 633-668.

Abernethy, M. A., Y. F. Kuang, and B. Qin. 2015. The influence of CEO power on compensation contract design. The Accounting Review 90 (4): 1265-1306.

Abernethy, M. A., and M. S. Wallis. 2018. Critique on the 'manager effects' research and implications for management accounting research. Journal of Management Accounting Research, forthcoming.

Adler, P. S., and S.-W. Kwon. 2002. Social capital: Prospects for a new concept. The Academy of Management Review 27 (1): 17-40.

Akbas, F., F. Meschke, and M. B. Wintoki. 2016. Director networks and informed traders. Journal of Accounting and Economics 62 (1): 1-23.

Allgood, S., and K. A. Farrell. 2003. The match between CEO and firm. The Journal of Business 76 (2): 317-341.

Armstrong, C. S., D. F. Larcker, G. Ormazabal, and D. J. Taylor. 2013. The relation between equity incentives and misreporting: The role of risk-taking incentives. Journal of Financial Economics 109 (2): 327-350.

Arya, A., and B. Mittendorf. 2005. Offering stock options to gauge managerial talent. Journal of Accounting and Economics 40 (1-3):189-210.

Ashbaugh-Skaife, H., D. W. Collins, W. R. Kinney, and R. LaFond. 2008. The effect of SOX internal control deficiencies and their remediation on accrual quality. The Accounting Review 83 (1): 217250.

Balsam, S., G. D. Fernando, and A. Tripathy. 2011. The impact of firm strategy on performance measures used in executive compensation. Journal of Business Research 64 (2): 187-193.

Barron, J. M., D. V. Chulkov, and G. R. Waddell. 2011. Top management team turnover, CEO succession type, and strategic change. Journal of Business Research 64 (8): 904-910.

Barth, M. E., W. R. Landsman, and M. H. Lang. 2008. International accounting standards and accounting quality. Journal of Accounting Research 46 (3): 467-498.

Bazerman, M. H., and F. D. Schoorman. 1983. A limited rationality model of interlocking directorates. The Academy of Management Review 8 (2): 206-217.

Bebchuk, L.A., A. Cohen, and A. Ferrell. 2009. What matters in corporate governance? The Review of Financial Studies 22 (2): 783-827.

Bebchuk, L. A., A. Cohen, and C. C. Y. Wang. 2013. Learning and the disappearing association between governance and returns. Journal of Financial Economics 108 (2): 323-348.

Bebchuk, L. A., and J. M. Fried. 2003. Executive compensation as an agency problem. The Journal of Economic Perspectives 17 (3): 71-92.

Bebchuk, L. A., and J. M. Fried. 2004. Pay without performance: The unfulfilled promise of executive compensation. Cambridge, MA: Harvard University Press.

Bebchuk, L. A., and J. M. Fried. 2006. Pay without performance: Overview of the issues. Academy of Management Perspectives 20 (1): 5-24.

$-39-$

This article is protected by copyright. All rights reserved. 
Belliveau, M. A., C. A. O’Reilly III, and J. B. Wade. 1996. Social capital at the top: Effects of social similarity and status on CEO compensation. The Academy of Management Journal 39 (6): 15681593.

Bennis, W., and J. O’Toole. 2000. Don't hire the wrong CEO. Harvard Business Review 78 (3): 170-176.

Bentley, K. A., T. C. Omer, and N. Y. Sharp. 2013. Business strategy, financial reporting irregularities, and audit effort. Contemporary Accounting Research 30 (2): 780-817.

Bergstresser, D., and T. Philippon. 2006. CEO incentives and earnings management. Journal of Financial Economics 80 (3): 511-529.

Berman, S. L., A. C. Wicks, S. Kotha, and T. M. Jones. 1999. Does stakeholder orientation matter? The relationship between stakeholder management models and firm financial performance. The Academy of Management Journal 42 (5): 488-506.

Bertrand, M., and A. Schoar. 2003. Managing with style: The effect of managers on firm policies. The Quarterly Journal of Economics 118 (4): 1169-1208.

Black, B. S., H. Jang, and W. Kim. 2006. Does corporate governance predict firms' market values? Evidence from Korea. Journal of Law, Economics, and Organization 22 (2): 366-413.

Bloom, M., and J. G. Michel. 2002. The relationships among organizational context, pay dispersion, and managerial turnover. The Academy of Management Journal 45 (1): 33-42.

Bowen, R. M., S. Rajgopal, and M. Venkatachalam. 2008. Accounting discretion, corporate governance, and firm performance. Contemporary Accounting Research 25 (2): 351-405.

Bruynseels, L., and E. Cardinaels. 2014. The audit committee: Management watchdog or personal friend of the CEO? The Accounting Review 89 (1): 113-145.

Burns, N., and S. Kedia. 2006. The impact of performance-based compensation on misreporting. Journal of Financial Economics 79 (1): 35-67.

Burt, R. S. 2000. The network structure of social capital. In Research in organizational behavior, ed. Sutton, R. I. and B. M. Staw. Greenwich, CT: JAI Press.

Bushman, R., Q. Chen, E. Engel, and A. Smith. 2004. Financial accounting information, organizational complexity and corporate governance systems. Journal of Accounting and Economics 37 (2): 167-201.

Campbell, D. 2012. Employee selection as a control system. Journal of Accounting Research 50 (4): 931966.

Cannella, A. A., Jr., and M. Lubatkin. 1993. Succession as a sociopolitical process: Internal impediments to outsider selection. The Academy of Management Journal 36 (4): 763-793.

Carpenter, M. A., G. Sanders, and H. B. Gregersen. 2001. Bundling human capital with organizational context: The impact of international assignment experience on multinational firm performance and CEO pay. The Academy of Management Journal 44 (3): 493-511.

Chang, Y. Y., S. Dasgupta, and G. Hilary. 2010. CEO ability, pay, and firm performance. Management Science 56 (10): 1633-1652.

Chang, W.-J., R. M. Hayes, and S. A. Hillegeist. 2016. Financial distress risk and new CEO compensation. Management Science 62 (2): 479-501. 
Cheng, Q., and T. D. Warfield. 2005. Equity incentives and earnings management. The Accounting Review 80 (2): 441-476.

Clayton, M. C., J. C. Hartzell, and J. Rosenberg. 2005. The impact of CEO turnover on equity volatility. The Journal of Business 78 (5): 1779-1808.

Cohen, J. R., L. M. Gaynor, G. Krishnamoorthy, and A. M. Wright. 2014. The effects of professional and social ties between the CEO and the audit committee on investor decision making. Working paper: Boston College, University of South Florida, and Northeastern University

Coleman, J. S. 1988. Social capital in the creation of human capital. American Journal of Sociology 94: S95-S120.

Coles, J. L., N. D. Daniel, and L. Naveen. 2006. Managerial incentives and risk-taking. Journal of Financial Economics 79 (2): 431-468.

Coles, J. L., N. D. Daniel, and L. Naveen . 2008. Boards: Does one size fit all? Journal of Financial Economics 87 (2): 329-356.

Core, J. E., and W. R. Guay. 2002. Estimating the value of employee stock option portfolios and their sensitivities to price and volatility. Journal of Accounting Research 40 (3): 613-630.

Core, J. E., R. W. Holthausen, and D. F. Larcker. 1999. Corporate governance, chief executive officer compensation, and firm performance. Journal of Financial Economics 51 (3): 371-406.

Cotter, J. F., A. Shivdasani, and M. Zenner. 1997. Do independent directors enhance target shareholder wealth during tender offers? Journal of Financial Economics 43 (2): 195-218.

Coughlan, A. T., and R. M. Schmidt. 1985. Executive compensation, management turnover, and firm performance: An empirical investigation. Journal of Accounting and Economics 7 (1-3): 43-66.

Cremers, K. J. M., and V. B. Nair. 2005. Governance mechanisms and equity prices. The Journal of Finance 60 (6): 2859-2894.

Crook, T. R., S. Y. Todd , J. G. Combs, D. J. Woehr, and J. D. J. Ketchen. 2011. Does human capital matter? A meta-analysis of the relationship between human capital and firm performance. Journal of Applied Psychology 96 (3): 443-456.

Dahya, J., and J. J. McConnell. 2005. Outside directors and corporate board decisions. Journal of Corporate Finance 11 (1): 37-60.

Daily, C. M., S. T. Certo, and D. R. Dalton. 2000. International experience in the executive suite: the path to prosperity? Strategic Management Journal 21 (4): 515-523.

Daske, H., L. Hail, C. Leuz, and R. Verdi. 2008. Mandatory IFRS reporting around the world: Early evidence on the economic consequences. Journal of accounting research 46 (5): 1085-1142.

Demerjian, P. R., B. Lev, and S. E. McVay. 2012. Quantifying managerial ability: A new measure and validity tests. Management Science 58 (7): 1229-1248.

Desarbo, W. S., C. A. Di Benedetto, M. Song, and I. Sinha. 2005. Revisiting the Miles and Snow strategic framework: Uncovering interrelationships between strategic types, capabilities, environmental uncertainty, and firm performance. Strategic Management Journal 26 (1): 47-74.

Dosi, G. 1988. Technical change and economic theory. London: Pinter.

Doty, D. H., W. H. Glick, and G. P. Huber. 1993. Fit, equifinality, and organizational effectiveness: A test of two configurational theories. The Academy of Management Journal 36 (6): 1196-1250. 
El-Khatib, R., K. Fogel, and T. Jandik. 2015. CEO network centrality and merger performance. Journal of Financial Economics 116 (2): 349-382.

Engel, E., R. M. Hayes, and X. Wang. 2003. CEO turnover and properties of accounting information. Journal of Accounting \& Economics 36 (1-3): 197-226.

Engelberg, J., P. Gao, and C. A. Parsons. 2012. Friends with money. Journal of Financial Economics 103 (1): 169-188.

Engelberg, J., P. Gao, and C. A. Parsons. 2013. The price of a CEO’s rolodex. The Review of Financial Studies 26 (1): 79-114.

Erkens, D. H., and S. E. Bonner. 2013. The role of firm status in appointments of accounting financial experts to audit committees. The Accounting Review 88 (1): 107-136.

Faleye, O., T. Kovacs, and A. Venkateswaran. 2014. Do better-connected CEOs innovate more? Journal of Financial and Quantitative Analysis 49 (5-6): 1201-1225.

Fama, E. F., and M. C. Jensen. 1983. Separation of ownership and control. Journal of Law and Economics 26 (2): 301-325.

Farrell, K. A., and D. A. Whidbee. 2003. Impact of firm performance expectations on CEO turnover and replacement decisions. Journal of Accounting and Economics 36 (1-3): 165-196.

Fee, C. E., and C. J. Hadlock. 2004. Management turnover across the corporate hierarchy. Journal of Accounting and Economics 37 (1): 3-38.

Fee, C. E., C. J. Hadlock, and J. R. Pierce. 2013. Managers with and without style: Evidence using exogenous variation. The Review of Financial Studies 26 (3): 567-601.

Festré, A. 2002. Innovation and business cycles. In The contribution of Joseph Schumpeter to economics: Economic development and institutional change, edited by R. Arena and C. Dangel-Hagnauer. London: Routledge.

Finkelstein, S., D. C. Hambrick, and A. A. Cannella. 1996. Strategic leadership. St. Paul, Minn.: West.

Fombrun, C. J. 1996. Reputation: Realizing value from the corporate image. Boston, Mass.: Harvard Business School Press.

Fracassi, C., and G. Tate. 2012. External networking and internal firm governance. The Journal of Finance 67 (1): 153-194.

Francis, J., A. H. Huang, S. Rajgopal, and A. Y. Zang. 2008. CEO reputation and earnings quality. Contemporary Accounting Research 25 (1): 109-147.

Gabaix, X., and A. Landier. 2008. Why has CEO pay increased so much? The Quarterly Journal of Economics 123 (1): 49-100.

Ge, W., and S. McVay. 2005. The disclosure of material weaknesses in internal control after the Sarbanes-Oxley Act. Accounting Horizons 19 (3):137-158.

Geletkanycz, M. A., and B. K. Boyd. 2011. CEO outside directorships and firm performance: A reconciliation of agency and embedded views. The Academy of Management Journal 54 (2): 335352.

Geletkanycz, M. A., B. K. Boyd, and S. Finkelstein. 2001. The strategic value of CEO external directorate networks: implications for CEO compensation. Strategic Management Journal 22 (9): 889-898. 
Geletkanycz, M. A., and D. C. Hambrick. 1997. The external ties of top executives: Implications for strategic choice and performance. Administrative Science Quarterly 42 (4): 654-681.

Gibbons, D. E. 2004. Friendship and advice networks in the context of changing professional values. Administrative Science Quarterly 49 (2): 238-262.

Gibbons, R., and K. J. Murphy. 1992. Optimal incentive contracts in the presence of career concerns: Theory and evidence. Journal of Political Economy 100 (3): 468.

Gompers, P., J. Ishii, and A. Metrick. 2003. Corporate governance and equity prices. The Quarterly Journal of Economics 118 (1): 107-155.

Gordon, J. N. 2007. The rise of independent directors in the United States, 1950-2005: Of shareholder value and stock market prices. Working paper: Columbia Law School.

Granovetter, M. S. 1973. The strength of weak ties. American Journal of Sociology 78 (6): 1360-1380.

Greene, W. H. 2012. Econometric Analysis. Pearson Education, Limited.

Hambrick, D. C. 1983. Some tests of the effectiveness and functional attributes of Miles and Snow's strategic types. The Academy of Management Journal 26 (1): 5-26.

Hartzell, J. C., and L. T. Starks. 2003. Institutional investors and executive compensation. The Journal of Finance 58 (6): 2351-2374.

Hayward, M. L. A., V. P. Rindova, and T. G. Pollock. 2004. Believing one’s own press: The causes and consequences of CEO celebrity. Strategic Management Journal 25 (7): 637-653.

Henry, E., and A. J. Leone. 2016. Measuring qualitative information in capital markets research: Comparison of alternative methodologies to measure disclosure tone. The Accounting Review 91 (1): 153-178.

Hermalin, B. E., and M. S. Weisbach. 1998. Endogenously chosen boards of directors and their monitoring of the CEO. The American Economic Review 88 (1): 96-118.

Houghton, S. M., A. D. Smith, and J. N. Hood. 2009. The influence of social capital on strategic choice: An examination of the effects of external and internal network relationships on strategic complexity. Journal of Business Research 62 (12): 1255-1261.

Huber, P. J. 1967. The behavior of maximum likelihood estimates under nonstandard conditions. Proceedings of the Fifth Berkeley Symposium on Mathematical Statistics and Probability, Volume 1: Statistics, 1 (1): 221-233.

Hwang, B.-H., and S. Kim. 2009. It pays to have friends. Journal of Financial Economics 93 (1): 138-158.

Indjejikian, R. J. 1999. Performance evaluation and compensation research: An agency perspective. Accounting Horizons 13 (2): 147-157.

Ittner, C. D., and D. F. Larcker. 1997. Quality strategy, strategic control systems, and organizational performance. Accounting, Organizations and Society 22 (3-4): 293-314.

Ittner, C. D., and D. F. Larcker. 1998. Are nonfinancial measures leading indicators of financial performance? An analysis of customer satisfaction. Journal of Accounting Research 36: 1-35.

Ittner, C. D., D. F. Larcker, and M. V. Rajan. 1997. The choice of performance measures in annual bonus contracts. The Accounting Review 72 (2): 231-255.

Ittner, C. D., D. F. Larcker, and T. Randall T. 2003. Performance implications of strategic performance measurement in financial services firms. Accounting, Organizations and Society 28 (7): 715-741. 
Javakhadze, D., S. P. Ferris, and D. W. French. 2016. Social capital, investments, and external financing. Journal of Corporate Finance 37: 38-55.

Johnson, J. L., C. M. Daily, and A. E. Ellstrand. 1996. Boards of directors: A review and research agenda. Journal of Management 22 (3): 409-438.

Johnson, S. G., K. Schnatterly, and A. D. Hill. 2013. Board composition beyond independence: Social capital, human capital, and demographics. Journal of Management 39 (1): 232-262.

Kale, J. R., E. Reis, and A. Venkateswaran. 2009. Rank-order tournaments and incentive alignment: The effect on firm performance. The Journal of Finance 64 (3): 1479-1512.

Kennedy, P. 1992. A guide to econometrics. $3^{\text {rd }}$ ed. Cambridge, Mass.: MIT Press.

Kilduff, M., and D. Krackhardt. 2008. Interpersonal networks in organizations: Cognition, personality, dynamics, and culture. Cambridge, New York: Cambridge University Press.

Kilduff, M., and W. Tsai. 2003. Social networks and organizations. London: Sage Publications.

Kleinknecht, A., K. Van Montfort, and E. Brouwer. 2002. The non-trivial choice between innovation indicators. Economics of Innovation and New Technology 11 (2): 109-121.

Krishnan, G. V., K. K. Raman, K. Yang, and W. Yu. 2011. CFO/CEO-board social ties, Sarbanes-Oxley, and earnings management. Accounting Horizons 25 (3): 537-557.

Kuang, Y. F., and G. Lee. 2017. Corporate fraud and external social connectedness of independent directors. Journal of Corporate Finance 45: 401-427

Kuang, Y. F., B. Qin, and J. L. Wielhouwer. 2014. CEO origin and accrual-based earnings management. Accounting Horizons 28 (3): 605-626.

Landsman, W., M. Lang, and S. Yeh. 2007. Governance and the split of options between executive and nonexecutive employees. Journal of Accounting, Auditing \& Finance 22 (2): 109-138.

Lang, L. H. P., and R. M. Stulz. 1994. Tobin’s q, corporate diversification, and firm performance. Journal of Political Economy 102 (6): 1248-1280.

Lang, M. H., K. V. Lins, and D. P. Miller. 2003. ADRs, analysts, and accuracy: Does cross listing in the United States improve a firm's information environment and increase market value? Journal of Accounting Research 41 (2): 317-345.

Larcker, D. F., S. Miles, and B. Tayan. 2014. The handpicked CEO successor. In Stanford Closer Look Series: Stanford Graduate School of Business and The Miles Group.

Larcker, D. F., S. Miles, and B. Tayan. 2016. Succession “losers”: What happens to executives passed over for the CEO job? In Stanford Closer Look Series: Stanford Graduate School of Business and The Miles Group.

Larcker, D. F., E. C. So, and C. C. Y. Wang. 2013. Boardroom centrality and firm performance. Journal of Accounting and Economics 55 (2-3): 225-250.

Lennox, C. S., J. R. Francis, and Z. Wang. 2012. Selection models in accounting research. The Accounting Review 87 (2): 589-616.

Lester, D. L., J. A. Parnell, and S. Carraher. 2003. Organizational life cycle: A five-stage empirical scale. The International Journal of Organizational Analysis 11 (4): 339-354. 
Leuz, C. 2003. Discussion of ADRs, analysts, and accuracy: Does cross-listing in the United States improve a firm's information environment and increase market value? Journal of Accounting Research 41 (2): 347-362.

Liu, Y. 2011. The impact of networks on CEO compensation, turnover, and appointment. Working paper, University of California, Riverside.

Malmendier, U., and G. Tate. 2009. Superstar CEOs. The Quarterly Journal of Economics 124 (4): $1593-$ 1638.

Marcel, J. J. 2009. Why top management team characteristics matter when employing a chief operating officer: A strategic contingency perspective. Strategic Management Journal 30 (6): 647-658.

McDonald, M. L., P. Khanna, and J. D. Westphal. 2008. Getting them to think outside the circle: corporate governance, CEOs' external advice networks, and firm performance. The Academy of Management Journal 51 (3): 453-475.

Mehran, H. 1995. Executive compensation structure, ownership, and firm performance. Journal of Financial Economics 38 (2): 163-184.

Michel, J. G., and D. C. Hambrick. 1992. Diversification posture and top management team characteristics. The Academy of Management Journal 35 (1): 9-37.

Milbourn, T. T. 2003. CEO reputation and stock-based compensation. Journal of Financial Economics 68 (2): 233-262.

Miles, R. E., and C. C. Snow. 1978. Organizational strategy, structure, and process, McGraw-Hill series in management. New York: McGraw-Hill.

Milgrom, P. R., and J. Roberts. 1992. Economics, organization, and management. Englewood Cliffs, N.J.: Prentice-Hall.

Miller, D. 1988. Relating Porter's business strategies to environment and structure: Analysis and performance implications. The Academy of Management Journal 31 (2): 280-308.

Miller, D. 1991. Stale in the saddle: CEO tenure and the match between organization and environment. Management Science 37 (1): 34-52.

Miller, D., and P. H. Friesen. 1984. A longitudinal study of the corporate life cycle. Management Science 30 (10): 1161-1183.

Mizruchi, M. S. 1996. What do interlocks do? An analysis, critique, and assessment of research on interlocking directorates. Annual Review of Sociology 22: 271-298.

Morse, A., V. Nanda, and A. Seru. 2011. Are incentive contracts rigged by powerful CEOs? The Journal of Finance 66 (5): 1779-1821.

Murphy, K. 1999. Executive compensation. Handbook of Labor Economics 3 (B): 2485-2563.

Murphy, K. J., and J. Zábojník. 2004. CEO pay and appointments: A market-based explanation for recent trends. The American Economic Review 94 (2): 192-196.

Murphy, K. J., and J. Zábojník. 2007. Managerial capital and the market for CEOs. Working paper, University of Southern California and Queen's University.

Murphy, K. J., and J. L. Zimmerman. 1993. Financial performance surrounding CEO turnover. Journal of Accounting and Economics 16 (1-3): 273-315. 
Nair, A., and L. Filer. 2003. Cointegration of firm strategies within groups: A long-run analysis of firm behavior in the Japanese steel industry. Strategic Management Journal 24 (2): 145-159.

Parrino, R. 1997. CEO turnover and outside succession: A cross-sectional analysis. Journal of Financial Economics 46 (2):165-197.

Pfeffer, J. 1991. Organization theory and structural perspectives on management. Journal of Management 17 (4): 789.

Pfeffer, J., and G. R. Salancik. 1978. The external control of organizations: A resource dependence perspective. New York, NY: Harper and Row.

Prendergast, C. 1999. The provision of incentives in firms. Journal of Economic Literature 37 (1): 7-63.

Roberts, M. R., and T. M. Whited. 2013. Endogeneity in empirical corporate finance. In Handbook of the economics of finance, edited by G. M. Constantinides, M. Harris, and R. M. Stulz, 493-572. Amsterdam: Elsevier.

Saint-Charles, J., and P. Mongeau. 2009. Different relationships for coping with ambiguity and uncertainty in organizations. Social Networks 31 (1): 33-39.

Santamaría, L., M. J. Nieto, and A. Barge-Gil. 2009. Beyond formal R\&D: Taking advantage of other sources of innovation in low-and medium-technology industries. Research Policy 38 (3): 507-517.

Schoorman, F. D., M. H. Bazerman, and R. S. Atkin. 1981. Interlocking directorates: A strategy for reducing environmental uncertainty. The Academy of Management Review 6 (2): 243-251.

Schumpeter, J. A. 1939. Business cycles: A theoretical, historical, and statistical analysis of the capitalist process. $1^{\text {st }}$ ed. 2 vols. New York: McGraw-Hill.

Sen, P. K. 2007. Ownership incentives and management fraud. Journal of Business Finance \& Accounting 34 (7-8): 1123-1140.

Shaw, K. W. 2012. CEO incentives and the cost of debt. Review of Quantitative Finance and Accounting 38 (3): 323-346.

Shen, W., and A. A. Cannella, Jr. 2002. Revisiting the performance consequences of CEO succession: The impacts of successor type, postsuccession senior executive turnover, and departing CEO tenure. The Academy of Management Journal 45 (4): 717-733.

Shen, W., and A. A. Cannella, Jr. 2003. Will succession planning increase shareholder wealth? Evidence from investor reactions to relay CEO successions. Strategic Management Journal 24 (2): 191-198.

Thompson, J. D. 1967. Organizations in action: Social science bases of administrative theory. New York: McGraw-Hill.

Tian, J., J. Haleblian, and N. Rajagopalan. 2011. The effects of board human and social capital on investor reactions to new CEO selection. Strategic Management Journal 32 (7): 731-747.

Tobin, J. 1958. Estimation for relationships with limited dependent variables. Econometrica 26 (1): 24-36.

Useem, M. 1982. Classwide rationality in the politics of managers and directors of large corporations in the United States and Great Britain. Administrative Science Quarterly 27 (2): 199-226.

Uzzi, B. 1997. Social structure and competition in interfirm networks: The paradox of embeddedness. Administrative Science Quarterly 42 (1): 35-67.

Vafeas, N. 1999. Board meeting frequency and firm performance. Journal of Financial Economics 53 (1): 113-142. 
Van den Steen, E. 2016. A formal theory of strategy. Management Science 63 (8): 2616-2636.

Van den Steen, E. 2017. Strategy and the strategist: How it matters who develops the strategy. Management Science, forthcoming.

Vancil, R. F. 1987. Passing the baton: Managing the process of CEO succession. Boston, MA Harvard Business School Press.

Waldman, D. A., G. G. Ramirez, R. J. House, and P. Puranam. 2001. Does leadership matter? CEO leadership attributes and profitability under conditions of perceived environmental uncertainty. The Academy of Management Journal 44 (1): 134-143. Is the highlighted information correct?

Weisbach, M. S. 1988. Outside directors and CEO turnover. Journal of Financial Economics 20 (0): 431460.

Westphal, J. D., and E. J. Zajac. 1995. Who shall govern? CEO/board power, demographic similarity, and new director selection. Administrative Science Quarterly 40 (1): 60-83.

White, H. 1980. A heteroskedasticity-consistent covariance matrix estimator and a direct test for heteroskedasticity. Econometrica 48 (4): 817-838.

Yermack, D. 1996. Higher market valuation of companies with a small board of directors. Journal of Financial Economics 40 (2): 185-211.

Yonker, S. E. 2016. Geography and the market for CEOs. Management Science 63 (3): 609-630.

Zhang, Y., and N. Rajagopalan. 2004. When the known devil is better than an unknown god: An empirical study of the antecedents and consequences of relay CEO successions. The Academy of Management Journal 47 (4): 483-500. 
TABLE 1

Sample selection procedure and sample distribution

\begin{tabular}{lr}
\hline Procedure & $\begin{array}{r}\text { Number of observations } \\
(N)\end{array}$ \\
\hline CEO successions during the period between 2000 and 2013 & 1,645 \\
Less: missing values in COMPUSTAT or CRSP & $(343)$ \\
Subtotal & 1,302 \\
Less: missing values in I/B/E/S, Thomson Reuters, and Incentive Lab & $(152)$ \\
Sample size & 1,150 \\
& \\
Sample distribution by year & \\
2000 & $7(0.61 \%)$ \\
2001 & $75(6.52 \%)$ \\
2002 & $57(4.96 \%)$ \\
2003 & $72(6.26 \%)$ \\
2004 & $92(8.00 \%)$ \\
2005 & $114(9.91 \%)$ \\
2006 & $104(9.04 \%)$ \\
2007 & $104(9.04 \%)$ \\
2008 & $105(9.13 \%)$ \\
2009 & $87(7.57 \%)$ \\
2010 & $94(8.17 \%)$ \\
\hline & $94(8.17 \%)$ \\
2013 & $127(11.04 \%)$ \\
2012 & $18.57 \%)$ \\
\hline
\end{tabular}

\section{Notes:}

In sample distribution, percentage of sample is reported in parentheses.

$$
-48-
$$

This article is protected by copyright. All rights reserved. 
TABLE 2

Descriptive statistics

\begin{tabular}{lccccc}
\hline Variable & Mean & SD & Q1 & Median & Q3 \\
\hline CEOTIES & 9.414 & 6.960 & 4.000 & 8.000 & 13.000 \\
$Q$ & 2.051 & 1.791 & 1.207 & 1.561 & 2.247 \\
ROA & -0.055 & 0.292 & -0.041 & 0.016 & 0.061 \\
PROSPECTOR & 0.000 & 1.000 & -0.625 & -0.287 & 0.213 \\
DEFENDER & 0.000 & 1.000 & -0.456 & -0.261 & 0.024 \\
CG & 0.000 & 1.000 & -0.924 & -0.160 & 0.900 \\
RETPRE24M & 0.109 & 0.370 & -0.093 & 0.058 & 0.227 \\
VOLPRE24M & 0.102 & 0.058 & 0.063 & 0.089 & 0.122 \\
LNTA & 8.031 & 1.680 & 6.785 & 7.905 & 9.209 \\
SEGMENT & 2.006 & 1.919 & 1.000 & 1.000 & 3.000 \\
FIRMAGE & 28.741 & 20.493 & 12.000 & 22.000 & 40.000 \\
HUMANCAP & 1.887 & 1.027 & 1.000 & 2.000 & 2.000 \\
OUTSIDER & 0.383 & 0.403 & 0.000 & 0.000 & 1.000 \\
US & 0.596 & 0.491 & 0.000 & 1.000 & 1.000 \\
CEOAGE & 52.77 & 6.54 & 48.00 & 52.00 & 57.00 \\
CEOBOARDTIES & 0.085 & 0.074 & 0.045 & 0.063 & 0.100 \\
GFC & 0.547 & 0.498 & 0.000 & 1.000 & 1.000 \\
MANUFACTURING & 0.477 & 0.500 & 0.000 & 0.000 & 1.000 \\
SALESGROWTH & 0.072 & 0.204 & -0.013 & 0.067 & 0.144 \\
NUMANALYST & 8.701 & 6.076 & 4.000 & 7.000 & 12.000 \\
SUNLAND & 0.418 & 0.493 & 0.000 & 0.000 & 1.000 \\
\hline Notes:Vabis & & & &
\end{tabular}

Notes: Variables are defined in the Appendix. 
TABLE 3

Pearson correlation matrix

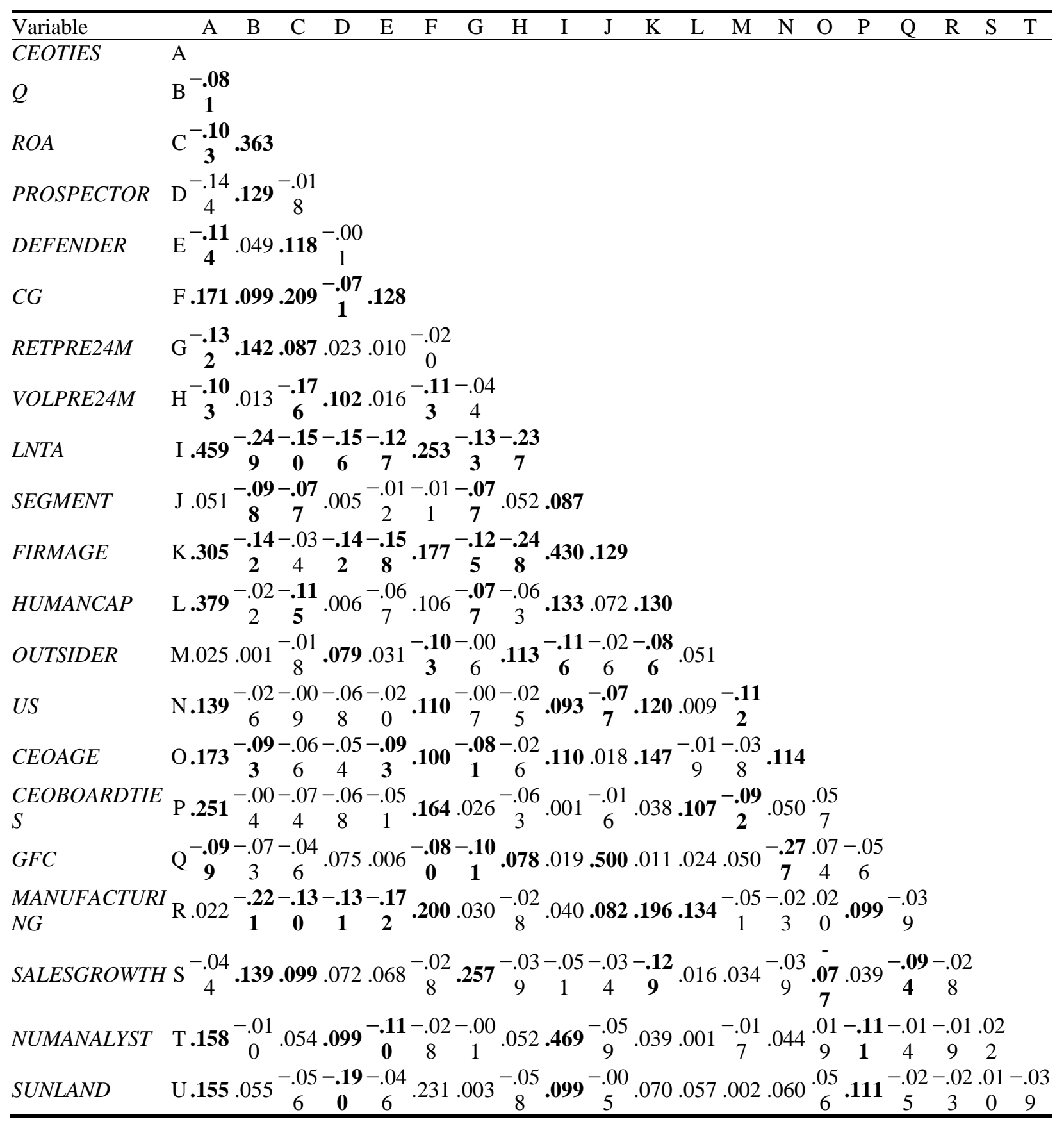

This article is protected by copyright. All rights reserved. 


\section{Notes:}

This table reports correlation coefficients. Correlations with $p$-value less than 0.01 are in bold. Variables are defined in the Appendix. 
TABLE 4

CEO selection

\begin{tabular}{|c|c|c|c|}
\hline \multirow[t]{2}{*}{ Variable } & \multicolumn{2}{|c|}{$\mathrm{DV}=$ CEOTIES } & \multirow{2}{*}{$\begin{array}{c}\mathrm{DV}=H I \_C E O T I E S \\
(3)\end{array}$} \\
\hline & $(1)$ & $(2)$ & \\
\hline \multirow{2}{*}{ PROSPECTOR } & $0.821 * * *$ & $0.566 *$ & $0.238 * * *$ \\
\hline & (3.318) & (1.777) & (2.966) \\
\hline \multirow[t]{2}{*}{ DEFENDER } & 0.081 & 0.139 & 0.012 \\
\hline & $(0.535)$ & $(0.720)$ & $(0.258)$ \\
\hline \multirow[t]{2}{*}{$C G$} & 0.259 & 0.176 & 0.168 \\
\hline & (1.332) & $(0.853)$ & $(0.903)$ \\
\hline \multirow[t]{2}{*}{$P R O S P E C T O R \times C G$} & & -0.160 & \\
\hline & & $(-1.017)$ & \\
\hline \multirow[t]{2}{*}{$D E F E N D E R \times C G$} & & -0.052 & \\
\hline & & $(-0.498)$ & \\
\hline \multirow[t]{2}{*}{ RETPRE24M } & -0.623 & -0.614 & -0.250 \\
\hline & $(-1.542)$ & $(-1.532)$ & $(-1.347)$ \\
\hline \multirow[t]{2}{*}{ VOLPRE24M } & 4.220 & 4.415 & -0.631 \\
\hline & (1.110) & (1.143) & $(-0.656)$ \\
\hline \multirow[t]{2}{*}{ LNTA } & $1.522 * * *$ & $1.525 * * *$ & $0.401 * * *$ \\
\hline & (11.688) & $(11.737)$ & (11.089) \\
\hline \multirow[t]{2}{*}{ SEGMENT } & $0.259 * * *$ & $0.256 * * *$ & $0.058 * *$ \\
\hline & (2.803) & $(2.756)$ & $(2.047)$ \\
\hline \multirow[t]{2}{*}{ FIRMAGE } & $0.028 * *$ & $0.028 * *$ & 0.003 \\
\hline & $(2.564)$ & $(2.556)$ & (1.030) \\
\hline \multirow[t]{2}{*}{ HUMANCAP } & $1.815^{* * * *}$ & $1.812 * * *$ & $0.348 * * *$ \\
\hline & $(11.136)$ & $(11.102)$ & $(6.871)$ \\
\hline \multirow[t]{2}{*}{ OUTSIDER } & $1.712 * * *$ & $1.723 * * *$ & $0.252 * *$ \\
\hline & (3.970) & (3.995) & $(2.088)$ \\
\hline \multirow[t]{2}{*}{ US } & 0.390 & 0.404 & 0.140 \\
\hline & (1.169) & (1.206) & $(1.260)$ \\
\hline \multirow[t]{2}{*}{ CEOAGE } & $0.127 * * *$ & $0.127 * * *$ & $0.035 * * *$ \\
\hline & (5.099) & (5.129) & $(4.419)$ \\
\hline \multirow[t]{2}{*}{ CEOBOARDTIES } & $16.130 * * *$ & $15.958^{* * *}$ & $3.972 * * *$ \\
\hline & $(6.602)$ & $(6.495)$ & $(5.699)$ \\
\hline \multirow[t]{2}{*}{ GFC } & $-4.761 * * *$ & $-4.787 * * *$ & -0.948 \\
\hline & $(-2.758)$ & $(-2.777)$ & $(-1.380)$ \\
\hline \multirow[t]{2}{*}{ MANUFACTURING } & -1.508 & -1.579 & 0.009 \\
\hline & $(-1.345)$ & $(-1.398)$ & $(0.042)$ \\
\hline \multirow[t]{2}{*}{ SUNLAND } & & & $0.193^{*}$ \\
\hline & & & $(1.836)$ \\
\hline \multirow[t]{2}{*}{ Intercept } & $-14.515^{* * *}$ & $-14.593^{* * *}$ & $-7.563 * * *$ \\
\hline & $(-7.190)$ & $(-7.257)$ & $(-11.851)$ \\
\hline Industry fixed effects & Included & Included & Included \\
\hline
\end{tabular}




\begin{tabular}{lccc}
\hline Variable & \multicolumn{2}{c}{ DV =CEOTIES } & DV $=$ HI_CEOTIES \\
\cline { 2 - 4 } & $(1)$ & $(2)$ & $(3)$ \\
\hline Year fixed effects & Included & Included & Included \\
$N$ & 1,150 & 1,150 & 1,150 \\
F-statistics & $14.17^{* * *}$ & $13.81^{* * *}$ & $362.62^{* * *}$ \\
(Chi-squared) & & & 0.343 \\
Adjusted $R^{2}$ (Pseudo & 0.441 & 0.441 & \\
$R^{2}$ ) & & & \\
\hline
\end{tabular}

Notes:

This table presents the results of regression analysis of CEO selection determinants. An OLS estimation is used in columns 1 and 2 where CEOTIES is the dependent variable. A probit estimation is used in column 3 where HI_CEOTIES is the dependent variable. Robust $t$-statistics are reported in parentheses in columns 1 and 2 and robust $z$-statistics are reported in parentheses in column $3 .{ }^{* *}, * *$, and $*$ indicate significance at the 1 percent, 5 percent, and 10 percent levels (two-tailed), respectively. Variables are defined in the Appendix. 
TABLE 5

Strategy, CEO social capital, corporate governance, and firm performance

Panel A: Tests of H2 and H3

\begin{tabular}{|c|c|c|c|c|}
\hline \multirow{2}{*}{ Variable } & \multicolumn{2}{|c|}{$\mathrm{DV}=R O A$} & \multicolumn{2}{|c|}{$\mathrm{DV}=Q$} \\
\hline & $(1)$ & $(2)$ & (3) & (4) \\
\hline \multirow[t]{2}{*}{ CEOTIES } & $0.001^{*}$ & 0.001 & 0.013 & $0.020^{*}$ \\
\hline & (1.928) & $(0.270)$ & $(1.382)$ & $(1.941)$ \\
\hline \multirow[t]{2}{*}{ PROSPECTOR } & $-0.024 * * *$ & $-0.026 * * *$ & -0.007 & -0.012 \\
\hline & $(-4.501)$ & $(-4.205)$ & $(-0.073)$ & $(-0.108)$ \\
\hline \multirow[t]{2}{*}{ DEFENDER } & $-0.006 * *$ & $-0.007 * *$ & -0.056 & -0.051 \\
\hline & $(-2.073)$ & $(-2.127)$ & $(-0.701)$ & $(-0.644)$ \\
\hline \multirow[t]{2}{*}{ CEOTIES $\times$ PROSPECTOR } & $0.001 * *$ & 0.001 & $0.019 * *$ & $0.030 * *$ \\
\hline & $(2.332)$ & $(0.342)$ & $(2.130)$ & $(2.008)$ \\
\hline \multirow[t]{2}{*}{ CEOTIES $\times D E F E N D E R$} & -0.001 & -0.001 & 0.002 & 0.004 \\
\hline & $(-0.726)$ & $(-0.672)$ & $(0.205)$ & $(0.363)$ \\
\hline \multirow[t]{2}{*}{$C G$} & $0.015 * * *$ & $0.015 * * *$ & 0.026 & 0.053 \\
\hline & $(5.445)$ & (3.488) & $(0.511)$ & $(0.610)$ \\
\hline \multirow[t]{2}{*}{ CEOTIES $\times C G$} & & 0.001 & & -0.009 \\
\hline & & $(0.701)$ & & $(-0.760)$ \\
\hline \multirow[t]{2}{*}{ CEOTIES $\times P R O S P E C T O R{ }^{*} C G$} & & $0.001^{*}$ & & $0.005^{*}$ \\
\hline & & $(1.847)$ & & $(1.784)$ \\
\hline \multirow[t]{2}{*}{$C E O T I E S \times D E F E N D E R \times C G$} & & 0.001 & & -0.002 \\
\hline & & $(0.573)$ & & $(-0.577)$ \\
\hline \multirow[t]{2}{*}{ RETPRE24M } & 0.004 & 0.004 & 0.302 & 0.290 \\
\hline & $(0.697)$ & $(0.643)$ & (1.555) & $(1.501)$ \\
\hline \multirow[t]{2}{*}{ VOLPRE24M } & $-0.382 * * *$ & $-0.373 * * *$ & $-4.412 * * *$ & $-4.348 * * *$ \\
\hline & $(-7.516)$ & $(-7.373)$ & $(-4.348)$ & $(-4.424)$ \\
\hline \multirow[t]{2}{*}{ LNTA } & $-0.014 * * *$ & $-0.013 * * *$ & $-0.473 * * *$ & $-0.461 * * *$ \\
\hline & $(-6.878)$ & $(-6.682)$ & $(-8.525)$ & $(-8.261)$ \\
\hline \multirow[t]{2}{*}{ SEGMENT } & -0.001 & -0.001 & -0.009 & -0.009 \\
\hline & $(-0.275)$ & $(-0.389)$ & $(-0.444)$ & $(-0.448)$ \\
\hline \multirow[t]{2}{*}{ FIRMAGE } & 0.001 & 0.001 & $0.008 * * *$ & $0.007 * * *$ \\
\hline & $(0.727)$ & $(0.727)$ & $(3.392)$ & $(3.367)$ \\
\hline \multirow[t]{2}{*}{ HUMANCAP } & $-0.003 *$ & -0.003 & 0.011 & 0.011 \\
\hline & $(-1.662)$ & $(-1.605)$ & $(0.241)$ & $(0.245)$ \\
\hline \multirow[t]{2}{*}{ OUTSIDER } & -0.006 & -0.005 & -0.162 & $-0.172 *$ \\
\hline & $(-1.142)$ & $(-1.018)$ & $(-1.591)$ & $(-1.700)$ \\
\hline \multirow[t]{2}{*}{ US } & 0.001 & 0.001 & -0.040 & -0.057 \\
\hline & $(0.125)$ & $(0.254)$ & $(-0.400)$ & $(-0.570)$ \\
\hline \multirow[t]{2}{*}{ CEOAGE } & $-0.001 * *$ & $-0.001^{* *}$ & $-0.015 * *$ & $-0.014^{* *}$ \\
\hline & $(-2.537)$ & $(-2.516)$ & $(-2.553)$ & $(-2.497)$ \\
\hline CEOBOARDTIES & -0.038 & -0.035 & 0.404 & 0.400 \\
\hline
\end{tabular}




\begin{tabular}{|c|c|c|c|c|}
\hline \multirow[t]{2}{*}{ Variable } & \multicolumn{2}{|c|}{$\mathrm{DV}=R O A$} & \multicolumn{2}{|c|}{$\mathrm{DV}=Q$} \\
\hline & $(1)$ & (2) & (3) & (4) \\
\hline & $(-1.402)$ & $(-1.327)$ & $(0.558)$ & $(0.553)$ \\
\hline \multirow[t]{2}{*}{ GFC } & $-0.068^{* * *}$ & $-0.072 * * *$ & $-2.178 * * *$ & $-2.050 * * *$ \\
\hline & $(-2.788)$ & $(-2.897)$ & $(-4.101)$ & $(-3.832)$ \\
\hline \multirow[t]{2}{*}{ MANUFACTURING } & 0.001 & 0.002 & 0.095 & 0.056 \\
\hline & $(0.045)$ & $(0.104)$ & $(0.342)$ & $(0.207)$ \\
\hline \multirow[t]{2}{*}{ SALESGROWTH } & $0.041^{* * *}$ & $0.042 * * *$ & $0.741 * * *$ & $0.727 * * *$ \\
\hline & (3.694) & (3.989) & $(2.786)$ & $(2.764)$ \\
\hline \multirow[t]{2}{*}{ NUMANALYST } & $0.002 * * *$ & $0.002^{* * *}$ & $0.051 * * *$ & $0.047 * * *$ \\
\hline & $(5.038)$ & $(5.195)$ & $(5.912)$ & $(5.555)$ \\
\hline \multirow[t]{2}{*}{ Intercept } & $0.364 * * *$ & $0.364 * * *$ & $7.604 * * *$ & $7.491^{* * *}$ \\
\hline & (11.318) & $(11.304)$ & (10.883) & $(10.825)$ \\
\hline Industry fixed effects & Included & Included & Included & Included \\
\hline Year fixed effects & Included & Included & Included & Included \\
\hline$N$ & 1,150 & 1,150 & 1,150 & 1,150 \\
\hline F-statistics & $9.56 * * *$ & $9.27 * * *$ & $5.86 * * *$ & $5.18 * * *$ \\
\hline Adjusted $R^{2}$ & 0.275 & 0.277 & 0.309 & 0.303 \\
\hline \multicolumn{5}{|c|}{ Panel B: Heckman second-stage analysis } \\
\hline \multirow[t]{2}{*}{ Variable } & \multicolumn{2}{|c|}{$\mathrm{DV}=\mathrm{ROA}$} & \multicolumn{2}{|c|}{$\mathrm{DV}=Q$} \\
\hline & $(1)$ & $(2)$ & (3) & $(4)$ \\
\hline \multirow[t]{2}{*}{ CEOTIES } & $0.001^{*}$ & 0.001 & 0.013 & $0.020^{*}$ \\
\hline & $(1.724)$ & $(0.207)$ & $(1.306)$ & $(1.781)$ \\
\hline \multirow[t]{2}{*}{ PROSPECTOR } & $-0.020 * * *$ & $-0.022 * * *$ & 0.025 & 0.041 \\
\hline & $(-3.460)$ & $(-3.250)$ & $(0.242)$ & $(0.342)$ \\
\hline \multirow{2}{*}{ DEFENDER } & $-0.007 * *$ & $-0.007 * *$ & -0.060 & -0.054 \\
\hline & $(-2.191)$ & $(-2.228)$ & $(-0.749)$ & $(-0.686)$ \\
\hline \multirow[t]{2}{*}{ CEOTIES $\times$ PROSPECTOR } & $0.001 * *$ & 0.001 & $0.019 * *$ & $0.029 * *$ \\
\hline & $(2.428)$ & $(0.394)$ & $(2.143)$ & $(1.994)$ \\
\hline \multirow[t]{2}{*}{ CEOTIES $\times D E F E N D E R$} & -0.001 & -0.001 & 0.003 & 0.004 \\
\hline & $(-0.436)$ & $(-0.486)$ & $(0.290)$ & $(0.445)$ \\
\hline \multirow[t]{2}{*}{$C G$} & $0.012 * * *$ & $0.012 * *$ & 0.002 & 0.011 \\
\hline & $(3.751)$ & $(2.538)$ & $(0.027)$ & $(0.122)$ \\
\hline \multirow[t]{2}{*}{ CEOTIES $\times C G$} & & 0.001 & & -0.008 \\
\hline & & $(0.776)$ & & $(-0.683)$ \\
\hline \multirow[t]{2}{*}{ CEOTIES $\times P R O S P E C T O R * C G$} & & $0.001^{*}$ & & $0.005^{*}$ \\
\hline & & $(1.754)$ & & $(1.856)$ \\
\hline \multirow[t]{2}{*}{ CEOTIES $\times$ DEFENDER $* C G$} & & 0.001 & & -0.002 \\
\hline & & $(0.569)$ & & $(-0.597)$ \\
\hline \multirow[t]{2}{*}{ MILLS } & 0.022 & 0.019 & 0.189 & 0.263 \\
\hline & (1.638) & (1.408) & $(0.699)$ & $(0.970)$ \\
\hline \multirow{2}{*}{ Intercept } & $0.191 * *$ & $0.208 * *$ & $5.174 * * *$ & $4.656 * * *$ \\
\hline & $(2.356)$ & $(2.570)$ & $(2.953)$ & $(2.668)$ \\
\hline
\end{tabular}




\begin{tabular}{lcccc}
\hline Variable & \multicolumn{2}{c}{$\mathrm{DV}=R O A$} & \multicolumn{2}{c}{$\mathrm{DV}=Q$} \\
\cline { 2 - 4 } & $(1)$ & $(2)$ & $(3)$ & $(4)$ \\
\hline Control Variables & Included & Included & Included & Included \\
Industry fixed effects & Included & Included & Included & Included \\
Year fixed effects & Included & Included & Included & Included \\
$N$ & 1,150 & 1,150 & 1,150 & 1,150 \\
$F$-statistics & $9.48^{* * *}$ & $9.20^{* * *}$ & $5.80^{* * *}$ & $5.17^{* * *}$ \\
Adjusted $R^{2}$ & 0.276 & 0.278 & 0.308 & 0.303 \\
\hline
\end{tabular}

Notes:

This table presents the results of OLS regression analysis of performance consequences of CEO social capital. In panel $\mathrm{A}, R O A(Q)$ is the dependent variable in columns 1 and 2 (3 and 4). In panel $\mathrm{B}$, following a Heckman two-stage procedure, $R O A(Q)$ is the dependent variable in columns 1 and 2 (3 and 4). The variable MILLS is calculated based on results reported in column 3 of Table 4. in both panels, robust $t$-statistics are reported in parentheses. ***, **, and * indicate significance at the 1 percent, 5 percent, and 10 percent levels (two-tailed), respectively. Variables are defined in the Appendix. 
TABLE 6

CEO social capital, corporate governance, and investment preferences

\begin{tabular}{|c|c|c|c|c|}
\hline \multirow[t]{2}{*}{ Variable } & \multicolumn{2}{|c|}{$\mathrm{DV}=S G \& A$} & \multicolumn{2}{|c|}{$\mathrm{DV}=R \& D$} \\
\hline & (1) & (2) & (3) & (4) \\
\hline \multirow[t]{2}{*}{ CEOTIES } & $0.001 *$ & $0.001 * *$ & 0.001 & $0.001^{* *}$ \\
\hline & $(1.844)$ & (2.447) & $(1.565)$ & (2.260) \\
\hline \multirow[t]{2}{*}{$C G$} & & $-0.079 * * *$ & & $-0.014 * * *$ \\
\hline & & $(-13.965)$ & & $(-4.182)$ \\
\hline \multirow[t]{2}{*}{ CEOTIES $\times C G$} & & $0.001 * *$ & & $0.001 * * *$ \\
\hline & & (1.988) & & $(2.678)$ \\
\hline \multirow[t]{2}{*}{ RETPRE24M } & -0.008 & -0.002 & -0.008 & -0.006 \\
\hline & $(-0.651)$ & $(-0.178)$ & $(-1.429)$ & $(-1.032)$ \\
\hline \multirow[t]{2}{*}{ VOLPRE24M } & $0.237 * *$ & $0.153 *$ & 0.053 & 0.016 \\
\hline & (2.570) & (1.934) & (1.257) & (0.390) \\
\hline \multirow[t]{2}{*}{ LNTA } & $-0.011 * * *$ & -0.002 & -0.002 & -0.001 \\
\hline & $(-3.420)$ & $(-0.972)$ & $(-1.138)$ & $(-0.290)$ \\
\hline \multirow[t]{2}{*}{ FIRMAGE } & -0.001 & -0.001 & $-0.001 * * *$ & $-0.001 *$ \\
\hline & $(-0.987)$ & $(-0.797)$ & $(-2.768)$ & $(-1.664)$ \\
\hline \multirow[t]{2}{*}{ HUMANCAP } & -0.001 & -0.002 & -0.001 & -0.001 \\
\hline & $(-0.200)$ & $(-0.595)$ & $(-0.524)$ & $(-0.013)$ \\
\hline \multirow[t]{2}{*}{ OUTSIDER } & -0.001 & -0.008 & 0.005 & 0.002 \\
\hline & $(-0.005)$ & $(-1.156)$ & (1.067) & $(0.541)$ \\
\hline \multirow[t]{2}{*}{ CEOAGE } & -0.001 & 0.001 & -0.001 & 0.001 \\
\hline & $(-0.585)$ & $(0.229)$ & $(-0.179)$ & (0.169) \\
\hline \multirow[t]{2}{*}{ LEVERAGE } & $-0.010 * * *$ & $-0.007 * * *$ & $-0.008 * * *$ & $-0.006 * * *$ \\
\hline & $(-2.661)$ & $(-2.643)$ & $(-5.498)$ & $(-4.130)$ \\
\hline \multirow[t]{2}{*}{ MTB } & $0.005 * *$ & $0.004^{* *}$ & $0.004^{* *}$ & $0.003^{* *}$ \\
\hline & (2.237) & (2.283) & (2.268) & (2.374) \\
\hline \multirow[t]{2}{*}{ ROAPRE3Y } & -0.119 & $-0.237 * * *$ & $-0.135 * * *$ & $-0.179 * * *$ \\
\hline & $(-1.562)$ & $(-3.432)$ & $(-3.146)$ & $(-4.303)$ \\
\hline \multirow[t]{2}{*}{ Intercept } & $0.111^{*}$ & $0.189 * * *$ & $0.063 * * *$ & $0.061^{* * *}$ \\
\hline & (1.938) & $(4.588)$ & $(2.867)$ & (2.877) \\
\hline Industry fixed effects & Included & Included & Included & Included \\
\hline Year fixed effects & Included & Included & Included & Included \\
\hline$N$ & 1,150 & 1,150 & 1,150 & 1,150 \\
\hline F-statistics & $16.69 * * *$ & $17.59 * * *$ & $10.28 * * *$ & $12.04^{* * *}$ \\
\hline Adjusted $R^{2}$ & 0.456 & 0.520 & 0.272 & 0.402 \\
\hline
\end{tabular}

\section{Notes:}

This table presents the results of OLS regression analysis of the effect of CEO social capital on SG\&A and R\&D spending average from $t+1$ to $t+3$. In columns 1 and 2 ( 3 and 4$), S G \& A(R \& D)$ is the dependent variable. 
Robust $t$-statistics are reported in parentheses. ${ }^{* *}, * *$, and * indicate significance at the 1 percent, 5 percent, and 10 percent levels (two-tailed), respectively. Variables are defined in the Appendix. 


\section{Appendix}

\section{Variable definitions}

\begin{tabular}{|c|c|}
\hline Variable & Description \\
\hline CEOTIES & $\begin{array}{l}\text { The number of connections to external organizations uniquely in the possession of } \\
\text { a new CEO measured right before she is appointed, relative to the old (outgoing) } \\
\text { CEO and board directors [BoardEx] }\end{array}$ \\
\hline HI_CEOTIES & $\begin{array}{l}\text { An indicator equal to one if a new CEO's social capital is in the top quartile of } \\
\text { our sample, and zero otherwise [BoardEx] }\end{array}$ \\
\hline Q & $\begin{array}{l}\text { Average Tobin's Q measured at the end of fiscal years from } t+1 \text { till } t+3 \text {. } \\
\text { Following Gompers et al. (2003), we approximate Tobin's } Q \text { by the market value } \\
\text { of assets divided by the book value of assets, where the market value of assets is } \\
\text { computed as book value of assets plus the market value of common stock less the } \\
\text { sum of the book value of common stock and balance sheet deferred taxes, } \\
\text { measured at the end of fiscal year } t \text { [COMPUSTAT] }\end{array}$ \\
\hline$R O A$ & $\begin{array}{l}\text { Average return on assets measured at the end of fiscal years from } t+1 \text { till } t+3 \\
\text { [COMPUSTAT] }\end{array}$ \\
\hline $\begin{array}{l}\text { PROSPECTOR } \\
\text { DEFENDER }\end{array}$ & $\begin{array}{l}\text { We employ a principal component analysis approach to construct two factor } \\
\text { scores that capture the extent to which a firm implements prospector-type and } \\
\text { defender-type strategies, respectively (Balsam et al. 2011); the factors are } \\
\text { constructed based on six items, including the ratio of R\&D to net sales, the ratio } \\
\text { of SG\&A to net sales, and the ratio of net sales to the cost of goods sold, the ratio } \\
\text { of PPE to total assets, the ratio of employees to total assets, and the ratio of sales } \\
\text { to capital expenditures. The variables are measured as annual average from } t-1 \\
\text { to } t-5 \text { [COMPUSTAT] }\end{array}$ \\
\hline$C G$ & $\begin{array}{l}\text { We employ a principal component analysis approach to construct a composite } \\
\text { variable with its value increasing with the quality of corporate governance } \\
\text { (Abernethy, Kuang, and Qin 2015). The factor score is calculated based on five } \\
\text { dimensions of corporate governance structure, including CEO-Chair duality, } \\
\text { board size, percentage of independent directors on board, institutional ownership, } \\
\text { and largest blockholder ownership [BoardEx; Incentive Lab; Thomson Reuters] }\end{array}$ \\
\hline RETPRE24M & Average monthly market return 24 months prior to CEO succession [CRSP] \\
\hline VOLPRE24M & $\begin{array}{l}\text { Standard deviation of monthly market return } 24 \text { months prior to CEO succession } \\
\text { [CRSP] }\end{array}$ \\
\hline LNTA & $\begin{array}{l}\text { The natural logarithm of book value of total assets at the end of the fiscal year } t \\
\text { [COMPUSTAT] }\end{array}$ \\
\hline SEGMENT & The number of business segments in which the firm operates [COMPUSTAT] \\
\hline FIRMAGE & Firm age, defined as the number of years that a firm has been listed [CRSP] \\
\hline HUMANCAP & $\begin{array}{l}\text { The number of awards and qualifications (e.g., CPA, MBA) held by the new CEO } \\
\text { [BoardEx] }\end{array}$ \\
\hline OUTSIDER & $\begin{array}{l}\text { An indicator equal to one if the CEO is recruited from outside the firm, and zero } \\
\text { if promoted from within the firm [BoardEx] }\end{array}$ \\
\hline US & $\begin{array}{l}\text { An indicator equal to one if the CEO has a U.S. nationality, and zero otherwise } \\
\text { [BoardEx] }\end{array}$ \\
\hline CEOAGE & The age of the new CEO in years [BoardEx] \\
\hline
\end{tabular}




\begin{tabular}{ll}
\hline Variable & Description \\
\hline CEOBOARDTIES & $\begin{array}{l}\text { The proportion of board directors who share at least one connection with the } \\
\text { newly appointed CEO right before the appointment, from prior work-related } \\
\text { activities or friendship activities (e.g., alumni, clubs, charities, volunteer } \\
\text { organizations, etc.) [BoardEx] }\end{array}$ \\
An indicator variable equal to one if the CEO succession takes place during or \\
after the 2007 Global Financial Crisis, and zero otherwise [BoardEx] \\
An indicator variable equal to one if the CEO succession takes place in a firm \\
from a manufacturing industry, and zero otherwise [BoardEx] \\
MANUFACTURING \\
SALESGROWTH \\
[COMPUSTAT]
\end{tabular}

-60 -

This article is protected by copyright. All rights reserved. 


\section{University Library}

\section{- M M I E E R VA A gateway to Melbourne's research publications}

Minerva Access is the Institutional Repository of The University of Melbourne

Author/s:

Kuang, Y;Abernethy, MA;Qin, B

Title:

The Relation between Strategy, CEO Selection, and Firm Performance

Date:

2019

Citation:

Kuang, Y., Abernethy, M. A. \& Qin, B. (2019). The Relation between Strategy, CEO Selection, and Firm Performance. Contemporary Accounting Research, 36 (3), pp.1575-1606. https:// doi.org/10.1111/1911-3846.12463.

Persistent Link:

http://hdl.handle.net/11343/286803 